\title{
Amerikalı Bir Gazetecinin Gözüyle Çanakkale Deniz ve Kara Savaşları: George Abel Schreiner ve Çanakkale Günlülkleri
}

\author{
Mustafa GÖLEÇ"
}

\begin{abstract}
$\ddot{O} z$
George Abel Schreiner I. Dünya Savaşı'nın başında Amerikan Associated Press Ajansı adına İstanbul'a gelir ve özel izinle Çanakkale'de deniz savaşlartnı ve Gelibolu'da kara savaşlarını yerinde izler. Bir yandan ajansına cepheden haberler gönderirken, bir yandan da bir günlük tutar. I. Dünya Savaşı henüz sona ermeden 1918 yılında New York'ta From Berlin to Bagdad adıyla yayınlanan bu günlük, adından olsa gerek, Çanakkale Savaşları ile ilgili literatürde ihmal edilmiştir. Oysa bir gazeteci ama aynı zamanda eski bir asker olarak Schreiner'in günlükleri savaşın askeri boyutu hakkında olduğu kadar siyasal ve toplumsal boyutları hakkında da zengin ve çarpıcı ayrıntılar içermektedir.

Bu çalışmada G. A. Schreiner'in gözünden Çanakkale Savaşları değerlendirilmektedir. Amerikalı muhabirin gözlem ve tespitleri farklı perspektifleri yansitan savaş sirasında tutulmuş başka günlükler ya da savaştan sonra yazılmış başka anılarla karşılaştırılmıștır. Ayrıca Schreiner'in gözlem ve tespitlerinin Çanakkale Savaşları konulu literatürdeki yeri ve bu literatüre muhtemel katkıları üzerinde durulmuştur.
\end{abstract}

Anahtar Kelimeler: I. Dünya Savaşı, Çanakkale Deniz Savaşları, Gelibolu Kara Savaşları, Savaş Günlüğü

Yrd. Doç. Dr., Fatih Sultan Mehmet Vakıf Üniversitesi Tarih Bölümü, mgolec@fsm.edu.tr. 


\title{
Nawal Wars of Dardanelles and Land Battles of Gallipoli from the Eye of an American Journalist: George Abel Schreinerand His Diary
}

\begin{abstract}
George Abel Schreiner comes to Istanbul at the beginning of the World War I on behalf of the American Associated Press Agency and observes naval wars in Dardanelles and land battles in Gallipoli by special permission. While he dispatches news from the front to his agency, he also keeps a diary. This diary, which is published in New York in 1918 before the end of the World War I under the name of "From Berlin to Bagdad", has been neglected in the literature about Dardanelles and Gallipoli wars. Whereas diaries of Schreiner as a journalist and also as an old soldier, include rich and stunning details about the political and social dimensions of the war as well as its military aspects.

In this study, Dardanelles and Gallipoli wars are evaluated from the eye of G. A. Schreiner. The American reporter's observations and theses are compared with the other diaries reflecting different perspectives kept during the war and with the memories written after the war. Besides, the place of Schreiner's observations and theses in the literature of Dardanelles and Gallipoli wars is stressed and possible contribution of them to this literature is focused.
\end{abstract}

Keywords: World War, Çanakkale Naval War, Gallipoli Land War, War Diary

\section{Giriş}

Amerikalı gazeteci George Abel Schreiner, I. Dünya Savaşı'nın başında Amerikan Associated Press ajansının savaş muhabiri olarak dokuz ay Türkiye'de bulunmuştur. Savaş sırasında başkent İstanbul ve İmparatorluğun farklı bölgelerindeki gözlem ve izlenimleri önemli olmakla beraber; hem Çanakkale'deki deniz savaşlarını hem de Gelibolu yarımadasındaki kara savaşlarını yerinden, Türk bataryalarından ve siperlerinden izlemiş olması onu ve yazdıklarını son derece önemli bir kaynak kılmaktadır.

Amerikalı savaş muhabirinin Çanakkale Savaşları ile ilgili bu ilk elden gözlem ve görüşmeleri ilgili literatürde hak ettiği ilgiyi görmemiștir. Büyük kısmı Çanakkale Savaşları́na ve savaş sırasında İstanbul'daki siyasal duruma hasredilmiş olmasına rağmen, daha farklı bir içeriği çağrıştıran From Berlin to Bagdad başlığı, günlüğünün Çanakkale Savaşları ile ilgili tanıklıklar arasında göz ardı edilmesinin hatta unutulmasının nedeni olmalıdır. ${ }^{1}$

1 Nitekim Çanakkale Savașları ile ilgili yapılmıș en kapsamlı bibliyografya çalıșmasında da yol arkadaşı RaymondSwing'in anılarına bile görece kısa bir Çanakkale Savaşı anlatısı içermesine rağmen yer 
Dâhiliye Nezareti Emniyet-i Umumiye Evrak Odası Kalemi evrakındaki "orduya ilhak ruhsatnamesinde" verilen eşkâline göre Schreiner uzun boylu olup sakalsız ve bıyıksızdır. Otuz beş yaşındadır. Alâmet-i fârikası olarak günlük gözlük kullandığı bildirilmektedir. Amerikan tabiiyetinden ve Protestan mezhebinden olduğu, İngilizce ve Fransızca bildiği (oysa Almanca da bilmektedir) kaydedilmiştir. Kendisini hep ajans muhabiri olarak tanıtsa da belgeye göre hem Amerikan Associated Press'in gezici muhabiri hem de Paper Daily News muhabiridir. ${ }^{2}$

İstanbul'da, Çanakkale'de ve Gelibolu'da Schreiner ile teşrik-i mesai eden, onun yakını ve hatta ortağı olan Chicago Daily News'ın Berlin muhabiri Raymond Swing'in yazdıkları da yukarıda verilen eşkâli doğrulamaktadır. Swing'e göre Schreiner Amerikanlaşmış bir Boer'dur. İri yarıdır ve dikkat çekici bir aksanla konuşmaktadır. Güney Afrika'da İngiltere'ye karşı Boer Harbi'nde topçu yüzbaşı olarak bulunmuştur. Swing onun İngilizlere karşı savaş vermiş biri olarak hararetli bir Alman taraftarı olmasını anlaşılabilir bulur. ${ }^{3}$

Schreiner gazeteci kimliği ileİ stanbul'da başta Sultan Mehmet Reşat olmak üzere, Sadrazam Prens Said Halim Paşa, Harbiye Nazırı Enver Paşa ve henüz Dâhiliye Nazırı olan Talat Bey gibi Osmanlı devlet adamları ile mülakatlar yapmıștır. Halide Edip Hanım gibi mütefekkirler, Hahambaşı Haim Nahum gibi azınlık cemaati liderleri görüştükleri arasındadır. Cephede erler ve alt ve orta düzey subaylarla teşrik-i mesai etmiş, aynı zamanda Çanakkale ve Gelibolu savunmasında görev alan Liman vonSanders, von Usedom, Mertens gibi Alman komutanların yanı sıra Cevat Paşa ve Esat Paşa gibi Türk komutanlarla da konuşmalar yapmıștır.

Schreiner'in tanıklığını önemli yapan hususlardan birisi tam olarak kendi ifadesiyle "eleștirel" olmaması, "olguların basit ve açı ilişkisi" ile yetinmesidir. Akademik olma hedefi gütmemesi, bilgilendirdiği kadar eğlendirmeyi de gaye edinmesi, günlük formunda yazması özgün bir bakıș açısı ortaya çıkarmıştır. Amerikalı muhabirin bilahare konu ile ilgili daha akademik ve eleştirel bir yayın yapmış olması, aynı yazarın kaleminden çıkmış iki farklı bakış açısını karşılaştırmalı olarak okuma imkânı da sunmaktadır.

Bu tanıklığı önemli kılan başlıca husus ise benzersiz bir tecrübe olmasıdır. Çanakkale Savaşları sırasında cepheye inceleme ziyareti biçiminde başka gazeteciler de götürülmüş, hatta bu gazetecilerin bazıları ile güven problemleri yaşanmıştır. Schreiner ise sadece R. Swing ile birlikte paylaştığı ayrıcalıklara sahip olarak, bizzat Enver Paşa'nın sağladığı ve onlara sınırsız özgürlük tanıyan bir tür "carteblanche" ile, üstelik

verilir ancak Schreiner'den ve eserlerinden söz edilmez. Bkz. A. Koyuncu-Ö. Keskin-C. S. Sönmez, Çanakkale Savaşları Bibliyografyası, Atatürk Araştırma Merkezi, Ankara 2010.

2 BOA, DH.EUM.VRK. 25/9-2.

3 RaymondSwing, “GoodEvening!”: A Professional Memoir, New York 1964, s. 62. 
kısa ya da belli bir süre için değil savaşın neredeyse başından sonuna dek tanı̆̆ı olmuştur: "Şimdiye kadar, Osmanlı ordusu ya da donanmasının hizmetinde olmayan başka hiçbir yabancı, Mr. Swing ve bana tanınan ayrıcalıkları tatmamıştır." ${ }^{4} \mathrm{Bu}$ sayede Schreiner savaş hakkında uzun soluklu tanıklıkların iki kaynağı olan üst düzey komutanlar ile daha alt rütbeli askerlerin anılarında görülebilen iki perspektifin ${ }^{5} \mathrm{~d}_{\mathbf{1}}$ şında, bunlardan farklı üçüncü bir perspektif sunabilmiştir.

Schreiner'in günlükleri birden fazla metinle sinanabilir ve bu yüzden de oldukça güvenilir oldukları söylenebilir. Örneğin deniz savaşlarına ilişkin olarak Mayın Grup Komutanı Binbaşı Nazmi Bey’in günlüklerí ${ }^{6}$ ile Schreiner'in günlükleri bombardımanların hedefleri, başlangıç ve bitiş saatleri ile bombardımanlara katılan gemilerin sayılarına kadar pek çok konuda büyük ölçüde örtüşmektedir. Öte yandan Nazmi Bey’in günlüğü özellikle mayınlarla ilgili meselelere odaklandığından, savaşın genel gidişatı hakkında Schreiner'in günlüklerinde çok daha kapsamlı gözlem ve yorumlar okunabilir. Nihayet Schreiner'in Çanakkale Savaşı ile ilgili anılarının, savaşı Osmanlı tarafından/perspektifinden anlatan diğer anılardan farklı olarak, Eylül 1918 gibi çok erken bir tarihte yani savaş daha bitmeden evvel yayınlanmış olması metnin güvenilirliği açısından önemli bir referanstır. ${ }^{7}$

\section{İstanbul'a Geliş ve Osmanlı Başkentinden Savaş Gözlemleri}

George A. Schreiner Trakya'daki kış şartlarının zorlaştırdığı epeyce gecikmeli bir tren yolculuğu sonrasında 9 Şubat 1915 sabahı Sirkeci'ye gelir. Oradan Pera'da Amerikan elçiliğinin yanında bulunan oteline geçer. ${ }^{8}$ İstanbul'da ilk iş olarak Ameri-

$4 \quad$ George AbelSchreiner, The CraftSinister, New York, 1920, s. 130. Bu iddia tartışma konusu edilebilir elbette, örneğin Swing anılarında sık sık yanlarındaki üçüncü bir gazeteciden Grunewald'dan söz eder. Yine de Schreiner'in ayrıcalıklarını paylaştığını kabul ettiği yegâne kişi olan RaymondSwing bile anılarını çok geç bir tarihte (1964'te) yayınlamıștır ve anılarının görece küçük bir bölümünü (46 sayfa) Türkiye'ye ve Çanakkale Savaşları'na ayırmıștır, ayrıca Schreiner'in metinleri kadar ayrıntılı değildir. Üstelik ilk elden gözlemlerine zamana zaman savaştan sonra yazılmış tarihsel monografilere feda eder. Örneğin Bu bile Schreiner'in tecrübesini günü gününe yazıldığı için "benzersiz" kılmaktadır.

5 Tarihe doğrudan tanık olmanın verdiği otorite ile yazılan I. Dünya Savaşı anılarını iki kategoride sinıflandıran Prost ve Winter'a göre savaşı yürüten siyasi ve askeri elitlerin kendi fillerini haklı çıkarmak ya da bağlamına oturtmak güdüsü ile kaleme aldıkları anıları daha alt rütbeden askerlerin ve erlerin anılarından farklıdırlar. Bkz. JayWinter-AntoineProst, The Great War in History / DebatesandControversies, 1914 tothePresent, Cambridge UniversityPress, New York, 2005, s. 174-175.

6 Mayın Grup Komutanı Binbaşı Nazmi Bey’in Günlüğüyle Çanakkale Deniz Savaşları(Yay. Haz. E. Şimşek - A. Güner), Deniz Basımevi, İstanbul 2010.

7 Türk tarafından kaleme alınan anıların çok daha geç tarihlerde yazılmış olması "tarihi anının yeniden oluşturulması sorunu" dolayısıyla bir otantiklik tartışmasına yol açabilmektedir. Bkz. AlexandreToumarkine, "Tanıklığın Önemi: Çanakkale Üzerine 'Osmanlı' Savaş Annları", Gallipoli in Retrospect 90 Years On / 90. Yıl Dönümünde Çanakkale Savaşlarını Düşünürken, Çanakkale 18 Mart Ünivrsitesi, Çanakkale, 2005, s. 108.

8 Günlüklerinde ismini vermediği bu otel Kroker Oteli'dir. Bkz. BOA, DH.EUM.VRK. 25/9-2. Tepebaşı'ndaki İngiliz Sefareti yakınında Pera Palas'ın biraz ilerisinde yer alan otel eski Amerikan Konsolosluğu'nun yanında bulunan ve bugün Beyoğlu Öğretmenevi olarak kullanılan binadır. 
kan elçiliği ile ilişki kurar, büyükelçi Morgenthau ile görüşür ve Küçük Kulüp’e kayıt yaptırır. Bu tabiidir, nitekim İstanbul'daki bir yetkili ile ilk önemli görüşmesini de aynı günün akşamı sonradan Osmanlı Donanması'na katılmış Amerikalı bir amiral olan Bucknam Paşa ile yapar. 20 Şubat'ta bir başka Amerikalı gazeteci Raymond E. Swing ile tanışır, kendisi ile bir tür ortaklık ilişkisi tesis eder. İki gazeteci İstanbul'daki görüşmelerini de, Çanakkale ve daha sonra Gelibolu'daki gezi gözlemlerini de beraber gerçekleştirirler. Raymond Swing de hatıralarında İstanbul'a geldiğinde buradaki tek Amerikalı gazetecinin Schreiner olduğunu, kendisi ile ittifak yaptıklarını, edindikleri her bilgiyi paylaşmak için anlaştıklarını yazar. ${ }^{9}$

İstanbul günleri Schreiner'in kâh bir oryantalist seyyah, kâh muhabir kimliğine büründüğü günlerdir. İstanbul'un kıtalar-arası jeopolitiği, etnik ve dinsel çeşitliliğii, dar sokakları, cumbalı ahşap evleri, haremlik-selamlık hayatı, feraceli-yaşmaklı-peçeli Müslüman kadınlar hakkında yazdıkları beylik Batılı seyyahların yazdıklarına benzer ama savaş ve savaş sırasında toplum hakkında gözlemleri ilk elden ve orijinal bilgilerdir.

Schreiner'in İstanbul'da yanıtını aradığı ilk soru Pera'da meydana geldiği iddia edilen katliamların gerçekliğidir. Konu ile ilgili bilgi talepleri muhataplarınca gülümsenerek karşılanır. Bu söylentilerin kaynağının Amerikalı bir muhabir olduğunu duyar. Bu gibi gerçek dışı haberler yüzünden Osmanlı hükümetinin yabancı muhabir ve gazetecilere ilişkin daha katı önlemler aldığını da öğrenir. ${ }^{10}$

Schreiner'in İstanbul'daki ilk günlerinde cevap aradığı sorulardan birisi de Osmanlı Devleti'nin öncelikle savaşa neden girdiği, ikinci olarak da neden Almanya safında girdiğidir. Bu tercih başkenti dolaşıp tanıdıkça ona şaşırtıcı gelmiştir. İstanbul'da Almanlara ve Avusturyalılara karşı gerçek bir muhabbet görmediğini, Türklerin Fransa ve Fransızcaya eğilimini Yunanlıların da paylaştı̆̆ını yazar. Ona göre Almanlar neredeyse sevilmemektedir. ${ }^{11}$ Türklerin onlarla müttefik olma nedeni de yüksek askeri vasıfları değildir. İtilaf korkusu, özellikle de İstanbul ve Boğazlar üzerindeki niyetleri dolayısıyla Ruslardan duyulan korku, Türkleri Almanlarla bir ittifaka adeta itmiştir. Alman elçiliği de Türkleri İtilaf devletlerinin Türkiye'den emin olmak için muhakkak Çanakkale'ye dayanacaklarına ikna edebilmiştir. İtilaf ordularının İstanbul'a girerlerse çıkarılamayabilecekleri kaygısı ile Osmanlı hükümeti merkezi Avrupa devletleri ile bir ittifaka hevesli olmasa da bunun ehven-i șer olduğu sonucuna varmıștır. ${ }^{12}$

Öte yandan Schreiner savaşa girme kararı üzerinde kamuoyunun bütününün

9 RaymondSwing, a.g.e, s. 62.15

10 George Abel Schreiner, From Berlin to Bagdad, Harpers\&Brothers Publishers, New York, 1918, s. 10.

11 ABD büyükelçiliğindeki görüşmesinde Schreiner Halide Edip'in onları takdir etmekle beraber Almanlara değil Fransızlara ve Fransız kültürüne yakınlık duyduğunu ifade eden sözlerini alıntılamaya değer bulur. Bkz. Schreiner, a.g.e., s. 25.

Schreiner, a.g.e., s. 24. 
hemfikir olmadığını da fark etmiştir. Önde gelen Türk devlet adamlarıyla yaptığı mülakatlarda, savaşa iştirak mevzubahis olduğunda,onları daha çok savunmada bulur. Bunun sebebi "Yaşlı Türkler"in hala harbe şiddetle muhalif olmaları, Jöntürkler arasında bile bu hususta ayrılıklar bulunması, Türkiye'yi savaşa sokanların aslında küçük bir azınlıktan ibaret olmasıdır. ${ }^{13}$

Bu “azınlığın” önde gelen bir ismi olarak Dâhiliye Nazırı Talat Bey ile 18 Şubat'ta bir mülakat yapan Schreiner, Amerikan büyükelçisinin referansı ile ayarlanan görüşmenin, Talat Bey'in kendisinin "loca biraderi” olduğunu anlamasıyla tatmin edici bir surette ilerlediğini yazar. Mülakatta Talat Bey Avrupa devletlerinin vaatleri ve eylemleri arasındaki çelişkilere işaret ederek Türkiye'nin mevcut devletler sistemindeki yerini bulmak zorunda olduğunu söyler. Türk hükümetinin savaşın patlak vermesinden bu yana Paris, Londra ve Petrograd'da nelerin konuşulup tartışıldığını bilerek İttifak devletleri safında savaşa girmeye karar verdiğini ifade eder. ${ }^{14}$

Benzer tezleri Schreiner Çanakkale'den çatışma haberlerinin geldiği günlerde Sadrazam Said Halim Paşa'dan da dinler. 26 Şubat'taki görüşmelerinde sadrazam, İtilaf hükümetlerinin Osmanlı hükümetine otuz yıl için Osmanlı Devleti'nin bütünlüğüne saygı duyacaklarını garanti ettikleri iddiasını doğrular. Fakat yakın siyasal tarihte diplomatik garantilerin çok da hesaba katılmadığını hatırlatır. Türkiye'nin bugüne kadar çok garantiler aldığını, daha fazlasını istemediklerini, kendisinin de garantilere hiç inancı olmadığını bildirir. Ayrıca bu şekilde bir "garanti"nin egemenlik haklarından feragat etmek demek olduğunu, bir başkasının koruma hakkını kabul etmek anlamına geldiğini öne sürer: "Korunan bir Türkiye, bağımlı Türkiye demektir. Biz bağımsız olmamız gerektiğine inanıyoruz, geçmişte olduğumuzdan daha bă̆ımsız."15 Dâhiliye nazırı gibi sadrazam da itilaf devletlerinin ne pazarlık yaptıklarını bildiklerinin altını çizmiştir.

Schreiner savaşın ekonomiye etkileri ile ilgili kendi ilk elden gözlemlerine pek yer vermez. İstanbul'daki ticaretin savaştan biraz etkilendiğine dair kendisine söylenenleri nakletmekle yetinir. Bunu savaşın diğer taraf ülkelerde de benzer etkilerini nazar-1 dikkate alarak tabii bulur. Öte yandan Türkiye'ye özgü bir sorunu da tespit

13 Schreiner, a.g.e., s. 29.

14 Talat Bey'in Schreiner'e söyledikleri çarpıcıdır: "Bu savaştan muzaffer çıkacağımız henüz tam belli değil. Göreceğiz. Bu arada biz açık görevimizi yapıyoruz, bu bizim sonumuz olsa bile. Yapabileceğimizin en iyisiyle itilafa karșı savașıyoruz. İtilaf ile savașabildiğimiz kadar uzun savașacağız. Eğer vaziyet aleyhimizde gelişirse, biz Osmanlıya yakışır bir biçimde batacağız. Milletimiz dahil olduğu mütemadi savașlarla kan kaybetti, soldu. Bu böyle devam ederse, Osmanlı Imparatorluğu'nun içinde bir tek gerçek Türk kalmadığı bir gün gelecek. Bizim dostlarımızın beklediği bir gün, bizim bazı vatandaşlarımızın gelmesi için dua ettiği bir gün. Evet, göreceğiz! Türk henüz burada. O burada olduğu müddetçe hesaba katılmak zorundadır. Biz sonuna kadar savașacağız. Bizim durma noktamız, bizim sonumuz olabilir. Fakat onlar saklandığımız söyleyemeyecekler. Dikkat etsinler!" Bkz. Schreiner, a.g.e., s. 29-31.

Schreiner, a.g.e., s. 60. 
eder: Burada ekonomiyi manipüle edebilecek büyük endüstriyel kuruluşlar yoktur ve küçük üreticilerin de devlet görevlilerinden kaçmak için ne yeteneği ne de motivasyonu vardır. Schreiner ekonomik sıkıntıları bizatihi savaşın kendisine bağlamaktansa savaş yolsuzluklarını gerekçe gösterir, en azından bunu ima eder. ${ }^{16}$

Öte yandan savaşın toplumsal psikolojiye etkileri konusunda daha birincil elden gözlemlerde bulunur. Pera, Galata, Taksim ve Suriçi'ndeki kahvelere gider, Yedikule civarındaki çingenelerle konuşur. Gördüğü, his ve fikir birliği içinde bir toplum değildir. Cepheden gelen haberlerin Türkler için kötü ise Ermeniler için iyi (ya da tam tersi) olduğunu, Rumların ise kimin kazanacağını umursuyor görünmediklerini yazar. Ona şehrin bombalanabileceği, eğer müttefik gemileri gelirse katliamlar olabileceği dillendirilmiștir. Toplumsal gruplar birbirlerinden korkmaktadır ve güvensizlik alabildiğine yayılmıştır. ${ }^{17}$

Bu toplumsal psikoloji yalnızca savaşın değil ama özel olarak Çanakkale'deki gelişmelerin bir sonucudur. Orta ve uzun vadede bile değil, birkaç gün içinde olabilecek şeylerin belirsizliği dolayısıyla halka açı mekânlardaki güvensizliğe devlet dairelerindeki kasvet eşlik etmektedir. Çanakkale'deki bataryaların itilaf donanmasına ne kadar süre dayanabileceğinden kimse emin görünmemektedir. ${ }^{18}$ Belirsizlik o raddededir ki Schreiner mevcut padişah V. Mehmet Reşad'in gizlice Beylerbeyi Sarayı'ndaki II. Abdülhamid'i ziyaret ettiği söylentilerini, Mehmet Reșad'ın neler olabileceğini öngörmesine bağlar ve Abdülhamid'in Çanakkale önündeki güçlerce sevilmeyen biri olmadığından yeniden hükümdar olabilmesini bile mümkün görür. ${ }^{19}$

Çanakkale'de deniz savaşını savaş muhabiri olarak bir ay kadar takip ettikten sonra Schreiner 1915 yılı nisan ayında yeniden İstanbul'dadır ve padișahın Cuma selamlığı törenine katılır. Valide Camii’ndeki töreni hala yeterince muhteşem olarak tarif etse de savaşın bu görkemli töreni de etkilediğini söylemekten geri kalmaz. Ca-

16 Schreiner, a.g.e., s. 22-23. Savașın İstanbul'daki toplumsal ve iktisadi hayata tesirleri için bkz. Muzaffer Albayrak, "Çanakkale Savaşları Sırasında İstanbul'da Sosyal Hayat ve Alınan Askeri Tedbirler", Gelibolu / Tarih, Efsane ve Anı (Ed: İ. G. Yumuşak-M. İlhan, İstanbul Medeniyet Üniversitesi, İstanbul, 2013, s. 249-264.

17 Schreiner göre Türkler kendilerini Rumlara karșı bir tür "davetsiz misafir", Ermenilere karşı ise "aclmasız efendi” hissetmektedirler. Rumların olası bir infialde Ermenilerden yana çıkacaklarına da Türklere yardımcı olacaklarına da ihtimal verilmemektedir. Rumların çoğunluğu için İstanbul'un itilaf devletlerinin eline geçmesi ile Türklerin elinde kalması arasında fark yoktur. Tek istekleri tanrının bu şehri Ruslardan korumasıdır. Ruslar dışında herkes, Almanlar bile, hoş karşılanacak misafirlerdir. Rumların Fransızların egemenliğini kutlayacakları, başka herhangi bir otoriteye karşı ise Türklere olduğu kadar kayıtsız olacakları yazılır. Schreiner, a.g.e., s. 38-40.

18 Schreiner bu psikolojiyi şöyle tablolaștırıyor: "Alman subaylar umutsuz bir vakaya bakan hekimler gibi. 'Avrupa'nın hasta adami' gerçekten umutsuzca hasta. Büyük bir operasyonun zamanı gelmiş gibi. Neyseki hasta artık bilincinde değil. Alman diplomatları uzun zaman önce narkoz vermişler. Sadrazam Said Halim Paşa, Dâhiliye Nazırı Talat Paşa, Harbiye Nazırı ve Osmanlı Ordusu Başkumandan Vekili Enver Pașa eter külahını ellerinde tutuyorlar. ... Bu hasta adamın son şansı. ...operasyon sürerken titremeler sona erecek." Schreiner, a.g.e., s. 42.

Schreiner, a.g.e., s. 45. 
minin bahçesi civarına birkaç polis ve yakınlardaki itfaiye istasyonlarından adamlar yerleştirilmiş olduğunu görür. Daha önce yerel garnizondan alay üstüne alayların gelip seremoniye katıldığını ama şimdi onların cephelerde olduğunu öğrenir. ${ }^{20}$

Schreiner günlügünün sonunda savaşın kent hayatına etkilerini değerlendirir. Osmanlı ekonomisi bir tarım ekonomisi olmasına, Osmanlı coğrafyasında bolca buğday, mısır ve hububat üretilmesine karşın savaşın daha altıncı ayında önce tahıl ihtiyacı sonra da kıtlığının baş gösterdiğini ve gıda sıkıntısının da ilk olarak İstanbul'u vurduğunu yazar. Mayıs ayında gıda fiyatları yükselmeye başlamış, Temmuz ayında şehirde ilk ekmek kuyrukları görülmüştür. Ekim'de şehrin alt gelir gruplarından çok sayıda insan buğday ekmeğinden tamamen mahrum kalmıştır. Bir tarım ekonomisi için olağanüstü olan bu durum aslında buğday yokluğunun bir sonucu değildir. İç Anadolu'da ve Suriye'de çok miktarda buğday bulunmakta ama taşınamamaktadır. Yüz binlerce ton ekmeklik tahıl uygun depolama imkânı bulunamadığı için çiftliklerde çürümüştür. Schreiner geçmişte hasat ettikleri ürünlerini hızla tüketen ya da birkaç hafta içinde satıp sevk eden Osmanlı tahıl üreticisinin depolama gibi bir sorununun olmadığını yazar. Yani savaşa hazırlıksız yakalanılmıştır. Zaten tek yönlü olarak hizmet verebilen, bazı hatlar üzerinde kesintiler bulunan ve taşıyabileceği tonajın tümüne cephelerdeki ordular ihtiyaç duyduğundan büyük oranda askeri nakliyata tahsis edilmiş olan demiryollarının soruna çare olabilmesi mümkün değildir. Geçmişte olduğu gibi Anadolu ve Suriye'de yetişen tahılın önemli bir yekûnunun Akdeniz limanlarından deniz yolu ile İstanbul'a nakli de Akdeniz'deki İngiliz ve Fransız gemileri Osmanlı sahillerini ablukaya aldıklarından ve Çanakkale'de de itilaf donanması bulunduğundan sürdürülememektedir. Orta ve Kuzey Anadolu'da üretilen tahılın Karadeniz limanlarından İstanbul'a nakli ise Karadeniz'deki Rus filosu tarafından engellenmiştir. İstanbul'un yegâne tedarikçisi kalan Batı Anadolu da ulaştırma altyapısının yetersizliğinden ihtiyacı karşılayamamış; İstanbul Trakya ve Marmara Denizi çevresindeki kaynakları adeta tüketip kurutmuştur. Schreiner seferberlik ve savaşa iştirakin tarımsal kesimin üretici güçlerini topraktan alıkoyduğuna da işaret eder.Toprağı sürüp ekecek erkek nüfusun çoğu silah altına alınmış ve yerlerini kadınların doldurabilmesi beklenmiştir.İstanbul'daki gıda sıkıntısı salt ekonomik ve toplumsal bir hadise değildir. Meselenin ahlaki ve politik veçheleri de vardır. Yiyecek yokluğu beraberinde yolsuzluk ve savaş vurgunculuğu söylentilerini de getirmiştir. Artan ekonomik baskıya çare olarak hükümetin vergileri olağanüstü artırması halkın şikâyetlerini daha da artırmıştır.

\section{Çanakkale'ye Gidiş}

Aslında Schreiner'in ajandasında Çanakkale'ye gitmek, itilaf donanmasının operasyonunu ve Türk müdafaasını yerinde görmek gibi planlar yoktur. Bu biraz tesa-

20 Schreiner, a.g.e., s. 169. 
düfi olmuş, bir dizi ayrıcalığı da beraberinde getirerek muhabirin Türkiye günlerini hem uzatmış hem de renklendirmiştir. Schreiner ile meslektaşı ve arkadaşı Raymond Swing Enver Paşa ile bir mülakat ayarlayabilmek için sonuçsuz kalan ısrarlı çabalarının nihayetinde, 25 Şubat günü, paşanın o gece Çanakkale'ye bir teftiş gezisine çıkacağını öğrenirler. Bu süresi belirsiz bir gezi olduğundan ve paşa orada uzun süre kalabileceğinden iki muhabir kendisiyle mülakat yapabilme şansından mahrum kalabileceklerinden korkmaktadırlar. Enver Paşa'nın sultanın yatıyla 06:09'da Çanakkale'ye hareket edeceği bilgisini almışlardır ama öncesinde bir mülâkat yapabileceklerinden ümitli olmaları için bir sebep yoktur.

Bu ümitsizliğin nedeni Schreiner arkadaşına Çanakkale'deki durumu izah ederken ortaya çıkar: Alman donanma üssüne doğrulattığı haberlere göre, İtilaf kuvvetleri Seddülbahir ve Kumkale'deki mevzileri 19/20 Şubat'tan itibaren bombalayıp susturmuşlardır. Türk topçusundan geriye çok şey kalmamıştır. Üstelik itilaf kuvvetleri İngiliz savaş gemilerinin en iyisi Queen Elizabeth de dâhil olmak üzere takviye kuvvetler getirmiştir. Müttefiklerin kruvazörlerden, destroyerlerden, torpido-botlardan, mayın gemilerinden, denizaltılardan, levazım gemilerinden, hastane gemilerinden ve başkalarından mürekkep filosu devasa boyutlardadır ve şimdilik sekiz İngiliz ve altı Fransız savaş gemisi yoldadır. Schreiner bu tabloda Kumkale ve Seddülbahir'deki Türk bataryalarının yeterli olmadıklarını, çoğunun yalnızca kendilerinin nerede olduklarını göstermeye yarayacaklarını söyler. Durum bir felaket durumudur. Orhaniye tabyasındaki bütün Almanlar öldürülmüştür, Enver Paşa sadece vaziyetin neye benzediğini görmeye gitmektedir ve bir mülakat yapabilmeleri imkân dâhilinde görünmemektedir. ${ }^{21}$

Haklı olarak Enver Paşa ile bir mülakat yapmayı ümit edemezler ama Çanakkale’ye gitmek için onun onayını alabileceklerini düşünürler. Yaptıkları işin riskini göze alarak bir araba ayarlarlar ve yağmurlu bir gecede Haliç'te mezkûr yatın bağlı olduğu rıhtıma gelirler. İskeledeki nöbetçilerin yanından, bir işleri olduğuna dair şüphe uyandırmadan, onlara bakmaksızın geçerler. Merdiven başındaki nöbetçiyi geçmek ise o kadar kolay değildir, nöbetçi bu iki yabancıya adlarını ve işlerinin mahiyetini

21 Bayur'a göre 19 Şubat'ta başlayan Çanakkale'nin dış tabyalarına saldırılar, taraflar arasındaki güç dengesizliği ve özellikle de silah menzilleri arasındaki fark dolayısıyla itilaf donanmasının tabii başarısı ile sonuçlanmış fakat bu başarı bir propaganda faaliyeti ile olduğundan büyük gösterilmiş, adeta itilaf güçleri tarafından işin yarısından çoğu bitirilmiş gibi bir tutum geliştirilmiştir. Bkz. Yusuf Hikmet Bayur, Türk İnkllâbı Tarihi, Cilt III, Kısım II, Türk Tarih Kurumu, Ankara, 1991, s. 62-63. Schreiner'in de şubat ayı sonunda henüz İstanbul'da iken bu propagandanın tesiri altında kaldığı, dahası Çanakkale'deki Türk savunma sistemi ve stratejisinden de bihaber bulunduğu anlaşılıyor. Özellikle Balkan Savaşları'nda yaşanan trajik yenilginin hemen sonrasında savaş sanayii neredeyse olmayan ve Alman yardımına bağımlı bulunan Osmanlı Devleti o kadar zayıf görülüyordu ki Norman Stone’a göre Britanya zırhlı dretnotlar çıkınca köhneleșen 1906 öncesinden kalma savaş gemilerini öne sürmeyi düşünebilmişti. Türk direnişinin ne kadar ihtimal dışı görüldüğünün çarpıcı bir örneği de şudur: Balkan Savaşları́na katılmış bir kurmay albay olan Doughty-Wylie karaya sadece asa ile çıkmıştır. Bkz. Norman Stone, Birinci Dünya Savaşı(Çev. A. F. Yıldırım), Doğan Kitap, İstanbul, 2012, s. 64-65. 
sorar. Enver Paşa'nın Alman kurmay başkanı von Bronsaart'ın ismini verirler ve onu görmek üzere geldiklerini söylerler. Bu işe yarar, kurmay başkanı gemidedir, gemiye girerler. Gemideki tedirgin arayışları sonunda güvertenin arka tarafında yöneldikleri bir kapı içeriden açılır ve von Bronsaart'ın şaşırmış yüzü ile karşı karşıya gelirler. İki yabancının nasıl olup da sultanın yatına girebildiğine hayret etmektedir. Dertlerini anlatırlar fakat von Bronsaart taleplerini imkânsız bulur ve gemiyi terk etmelerini ister. Amerikalı gazeteciler ısrarlıdır, Türkiye'ye askeri operasyonları izlemek için gelmişlerdir ve bunun için ekselansları ile konuşmak zorundadırlar. Bu sırada daha önceden tanıştıkları bir Alman subay Albay Yansen konuşmaya dâhil olur. ${ }^{22}$ Askerler için durum naziktir, o sırada bir otomobil yanaşır ve içinden Enver Paşa iner. Schreiner Enver Paşa ile görüşmeye de hapse ya da denize düşmeye de hazırdır. Alman subaylar ile Enver Paşa arasındaki samimi karşılaşmaya şahit olur. Ardından paşanın dikkatini sivil giyimli iki kişi çeker. Muhabirler yaklaşıp kendilerini tanıtırlar, paşanın memnuniyetsizliği yüzünden okunmaktadır.

Alman subaylar tarafından durumun paşaya açıklanması ayaküstü bir mülakata dönüşür. Amerikalı muhabirler İtilaf filosunun başarı şansını sorma fırsatı bulurlar. Enver Paşa bu soruyu şöyle cevaplar: "Eh, belki başarabilirler. Fakat kolayca başaramayacaklar. Savaş insanların hakkında kehanetlerde bulunmalarını gerektiren bir şey değildir. Söylemek zor. İşin bu kısmı hakkında tartışacak pozisyonda değilim." Boğazların girişindeki Türk bataryalarının çok iyi olmadığını kabul eden paşa, Çanakkale sahili boyundakilerin bundan daha iyisini yapacaklarını umduğunu söyler. Acelesi vardır ve mülakatı kısa kesmek zorundadır: "Biz Türkler Çanakkale’yi gerekirse son adamımızla savunacă̆ız. Bunun zor bir iş olduğunun farkındayız. Bu bizim kaynaklarımızı tüketecek ve kayıplarımız ă̆ır olacak. ...Biz Türkler hiçbir zaman pes etmeyiz, şimdi de etmeyeceğiz." 23

İki savaş muhabiri elbette bu ayaküstü “röportaj”la yetinmezler ve konuşmalarının sonunda Enver Paşa'dan sabah Çanakkale'ye gitmek için izin isterler. Kısa bir süre düşünen paşa bu talebi olumlu karşılar ve onlara güvenebileceklerine dair kurmay başkanının da onayını alır. Gerekli talimatları vereceğini söyler. Onlara savaş şartları ve askeri hukukun gereklerini hatırlattıktan sonra ${ }^{24}$ Çanakkale'ye gidebileceklerini ve her şeyi görebileceklerini söyler.

22 Nitekim Schreiner'in "Karargâh-ı Umûmiye Erkân-ı Harbiye Reisi V. Bronsart" imzalı "Orduya İlhak Ruhsatnamesi”nin Mülahazat kısmında "Yansen Bey’in tavsiyesiyle" ibaresi yazılıdır. Bkz. BOA, DH.EUM.VRK. 25/9-2.

24. "Osmanlı askeri hukuku altında size sağlanan yere kendinizi koyun ve onun hükümlerine uymayı kabul edin. Eğer cephedeki davranışınız sizin aleyhinize bu kanunun herhangi bir kısmının uygulanmasını gerektirirse, hiçbir şekilde burada elçiliğinizden yardım talep etmeyeceksiniz. Bir bölük ateşi ile yüz yüze kalmanız gerekse bile. Bunun karşılığında benden sizi gitmek isteyebileceğiniz her yere götürecek genel bir pasaport alacaksınız.” Bkz. Schreiner, a.g.e., s. 56. 
Söz verilen pasaportlar Schreiner ve Swing'in bekledikleri kadar çabuk gelmez ama Enver Paşa'nın Çanakkale'de meseleden haberdar ettiği İstanbul'daki Alman donanma üssü kumandanı Humann'dan cephede beklendikleri haberini alırlar. Yolculuklarını Humann ayarlar ve ellerinde onun verdiği bir mektuptan başka belge olmaksızın, 28 Şubat günü sabaha karşı Peyk-i Şevket adlı bir muhriple zor hava şartlarında yola çıkarlar. Öğleden hemen sonra Gelibolu kasabasını gördüklerinde artık top sesleri de kulaklarına gelmektedir. Schreiner'in bu sırada geç kalmış olduklarını düşünmesi ${ }^{25}$ itilaf donanmasının gücünden ve Türk savunmasının güçsüzlüğünden ne kadar emin olduğunu göstermektedir.

Çanakkale’ye hava karardığında varırlar. Karaya çıkmak hiç de kolay olmaz çünkü müttefik filosu boğazın girişinde olduğundan limandaki tüm ışıklar söndürülmüştür. Kendilerini götüren muhrip kayaların üzerine oturur, karanlıkta gelen bir tür mavnaya zorlukla geçerler ve bir römorkör yedeğinde limana girerler. Karaya çıarlar ama şehirde sokak lambaları yoktur, hiçbir ışık görülmemektedir, o kadar karanlıktır ki binaların ne kadar yüksek olduğunu bile anlayamazlar. Gece yarısı gibi, Türk sahil savunma teşkilatının genel müfettişi Amiral von Usedom Paşa’nın karargâhına varırlar ama pek sıcak karşılanmazlar. Paşa karargâhta değildir ve subaylar savaş şartları altında bu sivillerle meşgul olmak istememektedirler. Oysa yalnızca geceyi geçirebilecekleri bir yer aramaktadırlar ve karargâha gelen Amiral Merten Paşa'nın yardımı ile deniz tarafındaki rutubetli ve aynı zamanda Fransız ve İngiliz bombalarından kaçınabilmek için karanlık olan İstanbul Oteli'ne yerleşirler. Çanakkale günleri başlamıştır.

\section{Birinci Așama: Deniz Savașları}

İtilaf donanmasının Çanakkale önündeki stratejisinin dört ayağı bulunuyordu. Plana göre önce boğazın girişi tahrip edilecek, ikinci olarak ilk torpil (mayın) hattına kadar deniz temizlenecek, üçüncü olarak kati taarruz ile boğazın iki kıyısındaki tabyalar temizlenip mayın hatlarından İstanbul'a geçit açılacak, nihayet karaya çıkarma yapilarak kalan istihkâmlar ele geçirilip boğaza hâkim olunacaktı. ${ }^{26}$ Schreiner üçüncü aşamada akamete uğrayan bu planın ilk aşamasında İstanbul'dadır ama ikinci ve üçüncü aşamaları yerinde gözlemlemiştir.

George A. Schreiner 1 Mart'ta, Çanakkale'deki ilk gününde, öğleye doğru uyanır. İlk hissi şaşkınlıktır, bir bombardıman olmamaktadır. Bunu havanın kötü olmasına bağlar. Öğleden sonra bazı Alman ve Türk subaylar ile tanışır. Çanakkale'nin topografyası, nüfus yapısı, mimarisi ve genel durumu ile ilgili gözlemlerde bulunur. Şehrin müreffeh tabakası zaten Çanakkale'den ayrılmıştır. Onların boşalan evleri kıyı savun-

25 Schreiner, a.g.e., s. 68.

26 Bursalı Mehmet Nihat, Büyük Savaşta Çanakkale Seferi, İlhami-Fevzi Matbaası, İstanbul, 1926, s. 15. 
masında görevli Türk ve Alman subaylarca karargâh binaları olarak kullanılmaktadır. Fakirler ise hala şehirdedir ve bombardımanlarda ölüm tehlikesi altındadırlar.

Boğazın nasıl savunulacağına baktığında şehrin güneyine doğru iki sahil bataryasını, Çimenlik kalesi ve Anadolu Hamidiye tabyasını görür. Çimenlik kalesindeki dört geniş çaplı $(35,5 \mathrm{~cm})$ topun eski model olduğunu ama onun yaklaşık 800 metre güneyindeki Anadolu Hamidiye tabyasının buna nazaran daha modern olduğunu, on iki mevzii bulunduğunu, buradaki topların dördünün 35,5 cm diğer sekizinin ise 25,5 cm çapında olduğunu not eder. Bu hali ile Anadolu Hamidiye boğaz savunmasının en önemli unsurudur ve Schreiner'e göre açıkça yetersizdir. ${ }^{27}$ Direklere en gelişigüzel bir şekilde bağlanmış olan bataryalardaki elektronik haberleşme sistemleri açı hedef konumundadır. Belki de en önemlisi savaşan tarafların sahip oldukları silahların menzilleri arasındaki büyük farktır. Schreiner Türkler ve Almanların maksimum 14 bin 500 metre menzilli silahlarla en azından 18 bin metre menzilli silahlara sahip gemileri uzak tutabileceklerini nasıl olup da umduklarını anlayamaz. ${ }^{28}$

Schreiner ve arkadaşı Swing’in şehirdeki ilk günlerindeki önemli bir işleri de savaşı izleyebilecekleri uygun bir gözlem yeri bulmaktır. Subaylar onlara bataryalarda olmalarının kendileri için bir sakıncası olmadığını söyler. Schreiner ise bunu tehlikeli bulur. Üstelik savaşçılardan biri olmak istememekte, gözlemci olarak kalmak istemektedir. Sonuçta gözlem yeri olarak Sultaniye kalesinin tarihi kulesinin platformunu seçerler. Merten Paşa buranın Çimenlik kalesinin zeminindeki bataryaya atılan bazı mermilere hedef olabileceği uyarısında bulunsa da bu seçimi onaylar.

Gözlem yeri sorununu çözen muhabirler şehre dönerler. Öğleden sonra gökyüzü açılmış, fırtına yatışmış, deniz sakindir. İtilaf donanması uygun hava koşullarında boğazın girişine doğru harekete geçerler. Kumkale, Seddülbahir ve Erenköy yakınlarını tararlar. Öğleden sonra 2 civarı başlayan patlamalar saat 4:30'da itilaf gemilerinin çekilmesiyle sona erer. Akşam ise denizde arama mavnalarını gözlerler. İtilaf donanmasına ait olanlar Çanakkale'ye giriş bulmak, Türk donanmasına ait olanlar onları dışarıda tutmak için su üstündedir. Yine 1 Mart gecesi bazı itilaf mayın tarama gemilerinin körfeze girdikleri anlaşılır ve bunlar karadan Türklerin bu maksatla buraya yerleştirdikleri topçu bataryaları tarafından ateşe tutulur. ${ }^{29}$

27 Schreiner şöyle yazar: "Türklerin ekipmanlarının beni azıcık olsun etkilediğini söyleyemem. Silahlar menzil açısından yetersiz ve doğru ve etkili topçu ateşi yapabilmek için günümüzde kullanılan pek çok düzenekleri eksik." Schreiner, a.g.e., s. 77.

28 Schreiner, a.g.e., s. 78.

29 Binbaşı Nazmi Bey 1 Mart 1915 tarihinde günlüğüne şöyle yazar: "(Akşam) 10:30'da bir aralık düşman destroyerleri beraberlerinde arama tarama gemileri ile Tenger'e doğru hareket etmiş̧lerse de açllan ates üzerine geri çekilmişlerdir." Bkz. Mayın Grup Komutanı Binbașı Nazmi Bey’in Günlügüyle Çanakkale Deniz Savaşları, s. 93. Tevfik Rıza Bey'in günlükleri de Schreiner'in anlatısı ile büyük ölçüde örtüşmektedir. Sabah kar yağışlıdır, sonra hava düzelir, öğleden sonra Erenköy ve Kumkale top ateşine tutulur. Tevfik Rıza Bey, Çanakkale Günlükleri(Yay. Haz. T.Doğruöz-Y.Yücetürk-R.Gündoğdu), Kırklareli Üniversitesi Yay., Kırklareli, 2012, s. 74-75. 
2 Mart’ta itilaf savaş gemileri ilk kez Erenköy körfezine girerler. Fakat görüş mesafesi düşüktür, hava şartları onların lehine değildir. Öğleden biraz önce dört İngiliz hat gemisi, iki kruvazör ve bir sürü daha küçük gemi eşliğinde görünürler. Kruvazörler ve küçük teknelerin çoğunun çekilmesiyle Türk topçularının çok iyi hedef alamamaları için sürekli hareket halinde bulunan dört gemiden bombardıman başlar. İngiliz gemileri de, Anadolu ve Gelibolu tepelerindeki Türk obüsleri de cömertçe mühimmat harcamaktadır. Dardanos'taki ve İntepe üzerindeki bataryalar ve bazı obüs mevzileri hedeftedir. Atçıbaba tepesi yakınlarındaki bazı Türk obüsleri üç isabet kaydederler ama zırha karşı obüs mermisi cılız kaldığından bu önemsenmez. İtilaf bombardımanı da sonuçsuzdur. Gerek teknik sebepler gerekse topografya (Arazinin itilaf savaş gemilerinden bakıldığında görülememesi ve bu yüzden doğrudan ateş altına alınamaması Çanakkale savunması için büyük bir avantaj sağlıyordu.) bombardımanı etkisiz bırakır ve İngiliz gemileri iki saatlik bir bombardımandan sonra ciddi bir sonuç alamadan çekilirler. ${ }^{30}$

O günün gecesinde Schreiner ve arkadaşı gece bombardımanı ile uyanırlar, hızla gözlem yerine koşarlar ama silah sesleri aniden kesilir. Bir Türk projektörünün aydınlattığı boğazda bir tarama gemisinin gövdesini görürler. Bataryalarca ateşe tutulan gemi, boşa giden mermilerin projektör ışığı altında denizde göğe yükselttiği su kütlelerinden de anlaşıldığı üzere, isabet almamıştır. ${ }^{31}$

İtilaf filosu beş hat gemisi ile 4 Mart günü öğleye doğru yeniden Erenköy'e gelip körfezin üstündeki yamaçları vurur. Schreiner bulunduğu konumun hedef alınan bataryayı görmeye izin verdiğini ama bataryanın denizden görülemeyecek bir yerde olduğunu, bu yüzden dolaylı ateşe tutulduğunu yazar. Öğleden sonra gemiler Kumkale kalıntılarını tararlar, biri şiddetli müdafaa ateşi altında Küçükmenderes Çayı́nın ağzına kadar yaklaşır. İtilaf güçleri Kumkale’yi dinamitle tamamen silmek maksadıyla bir miktar asker de çıkarmış ancak bunu bekleyen ve bataryaların enkazında bir miktar piyade konuşlandıran Türkler girişimi akim bırakmışlardır. ${ }^{32}$

30 "İngiliz topçuları çok çalışııyorlardı. Üç geminin kulelerinden sarı ateș topları firlıyordu. Bir an sonra kırmızımsı dev duman bulutları yokluktan birden çıkıyor görünüyor ve saniyeler sonra Anadolu kıylsinda bir yerde büyük bir toprak gayzeri ve toz duman görüntüye karıșlyor. Dardanos Kalesi özellikle şiddetle cezalandırıld, İngilizlerin düşünmüş oldukları gibi. Fakat bu bir yanılgıydı. Kuleden oldukça açık görebiliyordum ki İngiliz ateşinin çoğu çok fazla yüksekti. İçinde Truva şehirlerinden birinin hala gömülü olduğu saygıdeğer eski çöğ yığınına bile isabet etmedi. ... Mermilerin çoğu bataryaların doğusundaki alanlara düştü ve hiçbir zarar vermedi. Gemilerin ateşi çok zayıf kaldi. Ben bunun sorumlusunun açık deniz olduğu sonucuna vardım." Schreiner, a.g.e., s. 82-83. Binbaşı Nazmi Bey de günlügüne itilaf ateşinin o günkü hedefinin Dardanos olduğunu not eder. Aynı yer.

31 Schreiner, a.g.e., s. 85-86.

32 Günlükte, bu hadise sırasında kaya parçaları ve elleriyle birçok adamı bertaraf ettiği söylenen Mustafa isimli bir onbaşının Demir Hilal madalyası kazandığı bildirilir. Bkz. Schreiner, a.g.e., s. 87. Tevfik Rıza Bey de o gün itilaf güçlerinin Kumkale'yi bombalayıp köyleri yaktıktan sonra motorların gözetiminde asker çıkardıklarını ancak bunların ateşle karşılandıklarını, çatışmada on yaralı ve iki şehit verildiğini yazar. Tevfik Rıza bey, a.g.e.,s. 78 . 
5 Mart'ta havanın sıcak, gökyüzünün bulutsuz, denizin sakin ve görüşün mükemmel yani hava şartlarının fevkalade olması, etkili bir itilaf saldırısı için uygun ortam sağlar. Düşman hat gemilerinin ve kruvazörlerinin bazıları Ege denizi üzerinde, Arıburnu'nda konuşlandırılır ve oradan Kilitbahir bataryaları ateşe tutulur. Dardanos ve Erenköy bataryaları da bombardımandan paylarını alır. Schreiner ve Swing'in bombardımanı izledikleri ve nispeten önemsiz bir hedef olacağından güvenli gördükleri kulenin platformu yakınına düşen mermiler muhabirlere bulundukları yerden ayrılmayı düşündürür. Schreiner bombardımanın ivme kazanmasını, hem bataryalar hem de şehir üzerine yağan toz ve duman bulutunu müttefiklerin Kilitbahir'i düşürmeyi kafalarına koydukları şeklinde yorumlar. Dumanlar arasından görülebilen, havaya yükselen büyük toprak kütleleri, patlamaların parıltıları ve sürekli artan ateştir. Kilitbahir üstünde taş taş üstünde kalmadığını düşünürler. ${ }^{33}$

Kilitbahir üzerindeki büyük bombardıman sırasında Schreiner Çimenlik bataryasındaki subaylar ve silahları başındaki askerlerin arasında bir hocanın dolaştığını görür. Hoca askerlere cesaret dolu sözler söylemektedir. Seccadesini yayıp, üzerine diz çöküp Allahtan lütfunu isteyen hoca, kızıl kuşak ve yeşil sarığı içinde, topçuları rahatlatmak için elinden geleni yapmaktadır. Askerlerin her birine tek tek hitap etmekte, bazılarının omuzlarını sıvazlamaktadır. Tek bir isabetli atışın kulenin dibindeki o sıkışık mevzide bir sürü hayatları söndürebileceği bu yerde ölüm hiç uzak değildir ve askerlerin bu özel alakaya ihtiyacı vardır. ${ }^{34}$

Müttefikler o gün 4:25 gibi çekildiklerinde Schreiner bombardımanın Çanakkale nüfusu üzerindeki sonucundan endişelidir. Öte yandan şark insanını olağanüstü soğukkanlı bulmaktadır. Çarşı vurulduktan sonra bile orada bir paniğin yaşanmadığını,

33 Binbaşı Nazmi Bey de günlüğune itilaf ateşinin o günkü hedefinin Kilitbahir olduğunu yazar. Bombardımanın bitis saatini ise yarım saat farkla 17:00 olarak not eder. Aynı yer. Tevfik Rıza Bey de o gün günlüğüne șunları yazmıștır: "Bugün öğleden sonra düşman Saroz körfezinden Kilitbahir’i bombaladı. Bu gerçekten korkunç, sanki kendilerini koruyamadan bütün tabyaların harap olmalarını göreceğiz." A.g.e., s.79.

34 Schreiner, s. 91-93. Savaş sırasında din görevlilerinin özellikle de tabur imamı sıfatı ile önemli bir fonksiyon gördükleri anlașılmaktadır. Örneğin Arıburnu'ndaki çatışmalarda bulunmuş Abdullah Fevzi Efendi anılarında çatışma öncesi tabur imamını ve askerlerin ruh hali üzerindeki tesirini şöyle anlatır: "Daha önce abdest almamız söylenmiști. Fakat çoğu arkadaşlar su bulup abdest alamadr. Ben onlara teyemmümü tarif ettim. Alay imamı rahmetli de söylemişti... Tabur imamı vadinin en üst tarafinda zafer ve ilahi yardım için el açıp dua yapıyordu. Ordu saf halinde dizilmiş idi. Hepsi artık inanmıs, mü’min vaziyetinde idiler. Dua bitince harekete hazır halde saf tutmamız emredildi." Bkz. Abdullah Fevzi Efendi, Canakkale Cephesinde Bir Müderris(Yay. Haz. Ali Osman Koçkuzu), İz yay., İstanbul, 2011, s. 198. Abdullah Fevzi Efendi bu çatışmada tabur imamı şehit olunca askerin diyanet konusunda çobansız bir sürü haline geliverdiğini, ordugahta ezan ve Kur'an okunmadığını, bir nasihatçi çıııp din diliyle askere nasihat etmez olduğunu yazar. Bunun üzerine tabur kumandanı askerlerin içinden Kur'an okuyabilen, imamlık yapabilen kimse arar ve Abdullah Fevzi Efendi'yi bu vazifeye getirir. Bu vazife o kadar önemlidir ki Abdullah Fevzi Efendi matematik ve hesap bildiğini, güzel defter tutabileceğini, kompozisyonunun da güçlü olduğunu bildirdiği halde şu cevabı alır: "Sana başka bir görev gerekmez, hakkıyla yaparsan imamlık sana yeter.Beş vakit müezzin ezan okusun, sen cemaate namaz kuldır, Yasin ve Fetih surelerini oku!" Kumandan daha sonra yanındakilere şöyle der: “...imamlık dışında bu ere askeri görev vermesinler..." Bkz. a.g.e., s. 255-256. 
deniz tarafının gün boyu meraklı adamlar, kadınlar ve çocuklarla kalabalık olduğunu yazar. Hasar tespit çalışmalarına girişince kendisine adam ve mühimmat kaybının hafif olduğu bildirilir. İtilaf gemileri de bataryaları vururken Türk silahlarının menzili dışında kalmaya ve Çanakkale'deki mayınlı alanlara ihtimam göstermişlerdir. ${ }^{35}$

5 Mart günü İtilaf gemilerinin yoğun bombardımanı sona erdiğinde hasar tespitine girişen Schreiner, görüştüğü subaylara mühimmat meselesini de açmayı dener ama imaları yanıtsız kalır. Buna rağmen mühimmat meselesinin "ayakkabının sıktı̆̆ı yer" olduğuna emindir. Alman topçu uzmanlarından itilaf donanması tarafından kullanılan mühimmatın da uygun olmadığı görüşünü duyar. Onlar zırha en iyi şekilde işlemek için yapılmış mermiler kullanmaktadır ama Çanakkale boyunca sözünü etmeye değer zırh bulunmadığından, siperler kumdan olduğu için, müttefiklerin mermileri bunların içinden geçememektedir. Merminin gidiş yönü üzerindeki küçük kum tanelerinin her biri bir fren işlevi görmekte ve merminin engelli ilerleyişi durduğunda hasar verici bir patlama için mermi yeterince derine nüfuz edememiş olmaktadır. Schreiner çelik zırhtan bir parça peynirden geçer gibi geçecek olan mermilerin bu kumların koruduğu mevzilere karşı neredeyse değersiz olduğunu yazar. ${ }^{36}$

Bombardıman 6 Mart günü sabah 9:30’dan akşam 4:30’a kadar kısa aralıklarla devam eder. Ön-dretnot tipi dört İngiliz gemisi Erenköy körfezinden Erenköy, Dardanos ve Kilitbahir'deki bataryaları ateşe tutar. Anadolu Hamidiye tabyası da aynı gün ilk kez bombardıman edilir. Bombaların düştüğü yerler Amerikalı muhabirlere yaklaşık 800 yarda mesafededir ve bazı şarapnel parçaları bulundukları kulenin duvarına ve platforma isabet etmiştir. Bunlar Schreiner'e göre sadece yakın gelecekte olacaklara dair bir mesaj vermek maksadını taşımaktadır. ${ }^{37}$ Nitekim Gökçeada, Bozcaada ve Limni'de devriye uçuşu yapan Osmanlı hizmetindeki Alman havacıların raporlarından ${ }^{38}$ da itilaf filosunun her geçen gün daha da büyüdüğü anlaşılmaktadır.

7 Mart'ta beş geminin katıldığı bombardıman daha kısa sürer. 12:15’te başlayıp 4:10'da biten bombardımanda Erenköy, Dardanos, Rumeli Mecidiye ve Anadolu Hamidiye dövülür. Bazı bombalar Truva yakınlarına düşer ve Schreiner ajansına yazdığı gönderide alaycı bir dille “Truva”nın bombardımana tutulduğunu yazmayı düşünür.

35 O gün bombardıman sonrası hasar tespit çalışmalarının ardından Schreiner ve arkadaşı Swing otele dönerler. Otelin Levanten kâhyası binanın çatısından Kilitbahir bombardımanını görmüştür, sıranın Çanakkale'ye geleceğinden emindir. Oteli kapatıp şehrin arkasındaki tepelere gitmeyi düşünmektedir. Bkz. Schreiner, a.g.e., s. 94.

36 Schreiner, a.g.e., s. 93-94.

37 Schreiner, a.g.e., s. 95-96. Binbaşı Nazmi Bey’e göre itilaf ateşi o gün 9:45’te başlamış, 16: 30’a kadar devam etmiştir. Nazmi Bey o gün saat 07:00'de Harbiye Nazırı Enver Paşa'nın Çanakkale’ye teşrif ettiğini yazar. Bkz. Aynı yer. Schreiner'in ise bundan haberi olmamış gibidir.

38 Şubat 1915 'te Çanakkale'ye gelen uçaklarla şehrin güneyinde Çanakkale Müstahkem Mevkii Komutanlığı’na bağlı olarak bir tayyare bölüğü teşkil edilmişti. Bilahare Nara Burnu'nda Alman Deniz Tayyare Bölüğü kurulmuştu. Almanya'dan gelen bu uçaklar silahsız iki kişilik keşif uçaklarıydı. Bu hususta ayrıntılı bilgi ve örnek keşif fotoğrafları için bkz. Çanakkale Savaşı’nın Bilinmeyen Cephesi: Hava Savaşları(Haz. Turan Tanyer), Türkiye Barolar Birliği, Ankara, 2010. 
Öğlen 1:10 ve 2:30 saatleri arasında bombardıman o kadar şiddetlenir ki Agamemnon ve Priamos'un ruhlarının da savaşa katıldığını hayal eder. Türkler mühimmat kullanımında gayet tutumludurlar. ${ }^{39}$ Bununla beraber o gün üç isabet kaydederler. İngiliz gemilerinden biri yan yatar ve limana çekilir. ${ }^{40}$

Bulundukları yer Amerikalı muhabirler için artık yeterince güvenli değildir. Amiral Merten Paşa'nın buraya bir 38.1'lik isabet etmesi durumunda ne olacağını bildiren uyarısıyla eski kuleyi daha önce burayı paylaştıkları muhaberecilere terk etmek zorunda kalırlar. Bir başka stratejik nokta için elleri boş dolaşırlarken Çimenlik ve Anadolu Hamidiye kaleleri arasındaki boş sahilde bombardımana yakalanırlar. Olup biteni sahilden takip ederken itilaf gemilerinin aniden bu iki kaleyi ateşe tutmalarıyla geri çekilemezler. Önlerinde Boğaz, arkalarında Rhodios Çayı (Koca Çay), yanlarında itilaf ateşi arasında kalırlar. Yapabilecekleri tek şey küçük bir kum yığınının arkasına sürünmektir. Üzerlerinden geçen itilaf mermilerini Schreiner "bir tünelde binlerce tekerleklerin gürültüsü̈ne benzetir. Sol taraflarında Anadolu Hamidiye'deki barakaların çatısı gitmiştir, kışla bahçesine bombalar düşmektedir ve Çimenlik'tekiler de zor durumdadır. Arkalarındaki alanda patlamalar olmakta, Çimenlik’i hedef alıp kısa düşen bombalar sahili vurmaktadır. Bunlardan birinin sipere yattıkları küçük kum yığınına çarpması ve onları öldürmesi an meselesidir. Türkler ise İtilaf gemileri menzil dışında kaldıklarından tek bir atış dahi yapmamaktadırlar. Müttefiklerin Çanakkale sahil savunma sistemine en azından darbe vurma kararlılığı ile gemilerin yaklaşması

39 Türk topçusunun mühimmat kullanımında tutumlu davranma zarureti zaman zaman İngilizlerin Türk bataryalarını susturma gayelerine eriştiklerini sanmalarına yol açmıştır. Alman subay Mühlman şöyle yazmaktadır: "Tahkimat şaşırtıcı bir direnme gücü gösteriyordu ve onları susturduklarını sanan saldırganları tekrar tekrar düş kırıklı̆̆ına uğratıyordu. Ĕ̆er Türk ateşi susarsa, bunun sebebi İngilizlerin zannettiği gibi, topların tahrip edilmiş olması değil, az sayıdaki cephane ile tutumlu hareket etme zorunluluğu idi." Bkz. Carl Mühlman, Çanakkale Savaşı / Bir Alman Subayının Anıları(Çev. Sedat Umran), Timaş Yay., İstanbul, 2009, s. 61.

40 Schreiner, a.g.e., s. 97. Binbaşı Nazmi Bey’in günlüğünde de beş büyük zırhlının katıldığı bombardımanın 12:00'den sonra başlayıp 04:08'de bittiği yazılıdır. A.g.e., s. 94. Çanakkale Savaşları'nda Türk tarafının en büyük problemi mühimmat yetersizliğidir. Gerek savaşa komuta eden subayların anıları, gerekse savaşa katılan askerlerin günlükleri bunun çarpıcı ifadeleri ile doludur. Örneğin Liman vonSanders anılarında piyade cephanesinin değil ama topçu cephanesinin en başından beri bir sorun olduğunu anlatır. İstanbul'da topçu cephanesi yapacak fabrika olmadığını, Almanya'dan cephane nakliyatına iki ülke arasındaki tarafsız devletlerin izin vermediğini, bu yüzden savaşın en başından beri Türk bataryalarının cephaneyi idareli kullanmak mecburiyetinde kaldıklarını bildirir. Üstelik kullanılan cephane de tesirsizdir: "Esirlerin ifadesine göre yirmi kırmızı mermiden çoğunlukla ortalama olarak ancak biri patlyyormuş. Bununla beraber bu yardım bile bizim için çok memnuniyet vericiydi. Çünkü bundan önce bazı bataryaların, kendi piyademizi ateşle himaye ettiğine inandırmak için bazen manevra mermisi kullandıkları bile oluyordu." Bkz. Liman vonSanders, Türkiye'de Beș Sene, Yeditepe Yay., İstanbul, 2006, s. 100. Bir topçu subayı da günlügüne şunları yazmıștır: "Bizim toplarımız onların büyük zırhlılarına karşı hiç nev'inde olduğu için bir şey yapamadık." (18 Mart 1915) "Üç yüz mermi kadar attık. Cephanemiz kalmadı. Ne yapacağız şaşırdık. Düşman bir dakikada elli-altmış mermi atıyor." (25 Nisan 1915) "Üç topa on bir mermimiz kaldı. Cephane bekliyoruz." (tarih verilmemiş) Bkz. Lokman Erdemir, “Çanakkale Boğazı Müstahkem Mevkii İntepe Topçu Grubu'ndan Bir Subayın Günlüğü”, Çanakkale Araştırmaları Türk Yıllığı, Yıl 11, Sayı 14, Bahar 2013, s. 45-46 ve s. 42. İtilaf ateşine mühimmat noksanı yüzünden pek az cevap verilebilmekte, bazen suskun kalınmaktadır. Her halükarda orantısız güçler arası bir çatışma yaşanmaktadır. 
Hamidiye bataryasını harekete geçirir. Hamidiye'nin ateşe karşıllı vermesi daha fazlasıyla karşılık görmesi anlamına gelecektir ve bu Schreiner'i arkasında oldukları kum yığını Hamidiye bataryasından uzakta olmadığından çok korkutur. Agamemnon tipi bir gemiyi gözüne kestiren bir Alman subayı menzilin 13 bin 400 metre olduğunu megafonla bildirir, dört kez ateş edilir, önce geminin ilerisinde bir su kütlesi yükselir, bir diğer bomba geminin ortasına kısa mesafede, üçüncü geride ve dördüncüsü yine geminin ortasına yakın düşer. Ardından Schreiner'in korktuğu gibi iki dakikalık bir zaman içinde itilaf gemileri ileri taretlerini Hamidiye ile yüz yüze getirip mermi yağmuru başlatırlar. İtilaf ateşi yüksekten seyreder ve mermiler çevreye isabet eder ancak bazıları kum yığınına birkaç ayak mesafe içinde düşer. ${ }^{41}$

İtilaf ateşi ne kadar şiddetli olursa olsun etkili olamamakta, sonuç alamamaktadır. Schreiner bulunduğu konumdan batarya yakınına düşen her mermiyi görebildiğini ama siper ve traverslerin o bombardımanda bir kez bile isabet almadığını yazar. Bombardımanın şiddetine karşı kulaklarını pamuk tıkaçlar ile korumaya çalışırlar. Ama bu kulak zarlarını patlamaların şok edici tesirlerinden korumaya yetmez. Özellikle Swing şiddetli baş ağrısından şikâyetçidir. Çimenlik'i geçmenin tehlikelerine karşın, sonunda sahilden ayrılmak için risk almaya Schreiner de ikna olur. Rhodius Çayı (Koca Çay) üzerindeki küçük bir köprünün karşısına geçtiklerinde çok yakınlarında sahilde bir bomba patlar, etrafa çelik parçaları yayılır. Çimenlik bataryasının güney avlusunda, bir mermi savaş muhabirlerinin sağında bulunan tek katlı bir binaya çakılır, patlamanın gücüyle yere düşerler. Gözlerini uçan cam parçalarından korumak için kollarıyla kapatırlar. Bataryanın avlusundan geçerken eski kulenin yerinde olduğunu ama kulenin güneybatı köşesinde büyük bir bomba çukuru açıldığını görürler. Çimenlik'in kuzeyindeki büyük kışla avlusuna varırlar ama bu noktadan Kilitbahir istihkâmlarında patlayan bombalar hariç hiçbir şey görülememektedir. Kale duvarına sürünüp, eski mendirek yakınından körfezi görecek bir mevzi ararlar ancak dalgakıranın içindeki sığ suda patlayan büyük bir bomba ve üstlerinden geçen parçalanmış çelik ve kaya yığınından canlarını zor kurtarabilirler. ${ }^{42}$

Schreiner'in daha önceden bildiği, pencereleri Erenköy körfezine bakan küçük bir Türk kahvesi, Kilitbahir'in güneyinde Boğaz’nn girişindeki görünümü kapatan bir burun olsa da, muhabirlere bombardımanı takip edecek güvenli bir alternatif görünür. Birkaç adım gitmişlerdir ki sağ geride bir başka bomba sığ suya düşer ve kaya, çelik, bakır parçaları ile çamur ve sudan bir çığın üzerlerinden geçmesi için yere yatarlar. Sonrasında koşmak isterler ancak yorgun ve bitkindirler. Zorlukla kahveye vardıktan kısa bir süre sonra da bombardıman durur.

41 Schreiner, a.g.e., s. 98-100.

42 Schreiner, a.g.e., s. 102-104. 
O gün Schreiner tehlikenin gerek Türkler gerek Alman subaylar tarafından giderek daha iyi anlaşıldığını yazar. Endişe zaman zaman halkta paniğe yol açacak eylemleri de beraberinde getirir. Kaymakamın Çanakkale halkına, şehirde kalanların bunu şehrin herhangi bir günde bombardıman edilebileceği bilgisiyle yaptıklarını belirterek hareket emri vermesi bu ruh halinin bir yansımasıdır. ${ }^{43}$ Oysa halk hemen ikna olmuş görünmez. 7 Mart günü, ağır bombardımana Çimenlik ve Anadolu Hamidiye bataryaları arasındaki sahilde yakalanarak hayati tehlikeler atlatan Schreiner ve arkadaşları, bombardımanı güvenli bir noktadan izlemek üzere günün sonuna doğru epeyce zahmetli bir yolculuktan sonra varabildikleri Erenköy körfezi manzaralı kahvenin Çanakkale sakinleri ile dolu olduğunu görür ve şaşırır. Birkaç Türk körfeze bakan bir pencere yanındaki masalarında onlara yer açar. Bombardıman durmadan hemen önce bir bombadan büyük bir çelik parçası bitişik bir aşçı dükkânı üzerinden küçük kahveye isabet eder. Schreiner kahvehanedeki erkeklerin sakinliğini dikkat çekici bulur. Bu kadar yakın bir tehlike altında olup buna aldırmamalarını doğunun kaderciliğine bağlar. ${ }^{44}$

Ne var ki ertesi gün halkın tepkisi değişmiş görünmektedir. Schreiner 7 Mart’taki bombardımanın Çanakkale halkını başka bölgelere gitmeye ikna ettiğini düşünür. Bomba parçalarıyla yıkılan çarşı ve aşevi binası, insanlara tam isabet alabilecek bir bombanın muhtemel korkunç sonuçlarını göstermiş; bombalar kaymakamın ve Cevat Paşa'nın ilan ve ikazlarından çok daha etkili olmuştur. Schreiner ve arkadaşı Swing gece saat 03:00'te gürültüye uyanırlar. İskele üzerinde büyük bir kalabalık vardır. Herkes bir mavnaya binme telaşındadır. Erkek, kadın, çocuk ve bagaj mavnaları tıka basa doldurmaktadır. Schreiner Nara dışında birkaç vapurun mültecileri beklediğini öğrenir. İnsanlara iç bölgelerdeki akrabalarına gitmeleri önerilse de parası olanlar İstanbul'a gitmektedir. Göç eden kalabalıkta Rumlar, Türkler, Ermeniler vardır. Etnik kimlikler ve farklılıklar kadınların kıyafetlerinde ifadelerini bulmaktadır. Hıristiyanlar şal, Müslümanlar yaşmak ve ferace giymişlerdir. Evlerini terk etmek zorunda kaldıkları bu koşullarda oldukça hırpani gözükmektedirler. Öte yandan bu bir fakirler kalabalığı da değildir, bir miktar parası olanlar kiralayabildikleri mavnalarla ev eşyalarının da bir kısmını mesela tabureler, büyük pirinç tepsiler, birtakım çini ve halı balyaları ve bazı evcil hayvanlarını yanlarında götürmektedirler. Kalabalığın çeperlerinde çok fakir insanlar da bulunmaktadır, çekingen bir biçimde kendilerini İstanbul'a veya bir başka yere götürecek ücreti temin etme çaresi aramaktadırlar. Bazıları eşyalarını satılığa çıkarsa da bunlardan çok daha iyi eşyaları arkasında bırakıp giden kalabalıktan bunlara talip olan çıkmamaktadır. Düzeni sağlamak üzere askerler ve jandarma gelir ama karmaşa daha da artar. Göçmenlerin yanlarına alabilecekleri az miktardaki eşyaları gürültünün başlıca sebebidir. Schreiner bir önceki gün göz-

43 Schreiner, a.g.e., s. 97.

44 Schreiner, a.g.e., s. 105-106. 
lemlediği metanetli ilgisizliğin ortadan kaybolduğunu, nüfusun aniden delirmiş gibi göründüğunü yazar. Son mavnaların da kendilerini bekleyen buharlı gemilere doğru uzaklaşması geride kalanları çılgına çevirir, jandarma ve subaylar hadiselere müdahale ederler. Öğleye doğru ortalık sakinleşmiş, kalanlar evlerine dönmüştür. ${ }^{45}$

Ertesi gün, 8 Mart'ta, Schreiner ve arkadaşları Kilitbahir'e gitmek ve bombardımanın verdiği hasarı yerinde görmek üzere bir mavna kiralarlar. Mayın alanları dolayısıyla zor ve olması gerekenden uzun bir yolculuk olur. Vardıklarında müttefiklerin ateşinin büyük etkisi olmadığını, verilen hasarın "gülünç derecede küçük" olduğunu görürler. Tek bir silah tahrip edilmemiş, küçük bir kışla, birkaç baraka ve bir dizi ek bina tahrip görmüştür. Büyük kışla ve diğer beş bina ise hafif hasarlıdır. Türk topçusunun kayıpları iki ölü ve yedi de yaralıdan ibarettir. Sahil savunma sisteminin ötesinde ise durum oldukça farklıdır, Kilitbahir kasabasının güney kısmı ciddi zarar görmüştür. İtilaf mermilerinin çoğu buraya isabet etmiş, bombalar binaları tutuşturmuştur. Durum Türkler açısından güven tazeleyicidir, o kadar ki istihkâm komutanı Amerikalı muhabirlere itilaf kuvvetlerinin bölgesini geçmek için zannettiklerinden daha çok kafa yormak zorunda olacaklarını söyler. Schreiner istihkâmlardan sonra kasabada da gözlemlerde bulunur. Evler terk edilmiştir. ${ }^{46}$

Sonraki birkaç gün ciddi bombardıman olmaz. Oysa hava şartları bombardıman için son derece uygundur. Baharın habercisi bir havada, 11 Mart günü, Schreiner şehir meydanında küçük bir kahvenin önünde ağaç altında uzun vakit geçirir. Şehirde hayatın bir yandan sürmekte olduğunu gözlemler. İnsanlar çay kahve ısmarlamakta, sigara ikram etmekte, evlerine yemeğe davet etmektedir. Kahveci müşterileri güneşlensin diye masaları dışarı çıkarmıştır. Uzun uzun, saatlerce caddede akan askeri trafiği izler. Piyade alayları ağır yürüyüşle önlerinden geçmektedirler. Bazıları güneye doğru Kumkale'ye gitmekte, bazılarıssa dönmektedir. Top ve mühendislik ekipmanları bir o yana bir bu yana taşınmakta, deve kervanlarının sonu gelmeyecek görünmektedir. Kent peyzajında savaş gerekçesi ile bazı değişikliklere gidilmektedir. Beyaz minareler ve evler, Çanakkale ve Kilitbahir'deki kalelerin büyük kuleleriyle bazı bataryaların beyaz taş kaplamaları itilaf gemileri ve topçularının işini kolaylaştırdığı için, bir önlem olmak üzere, bu yüzeyler siyaha boyanır. Anadolu Hamidiye'nin arkasındaki görkemli söğüt ağaçları gibi dikkat çekici bazı ağaçlar da kesilir. ${ }^{47}$

Yine11 Mart'ta Schreiner günlüğüne Mondros Limanı́nda çok sayıda müttefik gemileri bulunduğunu ve içeriden kaynaklara göre diğerlerinin de Çanakkale istikametinde olduğunu not düşer. İngiliz ve Fransızlar şimdiye kadarkilerden çok daha

45 Schreiner, a.g.e., s. 107-110.

46 İçine girdikleri boş bir evin kapısını açık bulurlar. Ahşap divan, bir çekmece, birkaç parça eski püskü halı ve kilim evde bırakılmış, minderler ile yorgan ve yastıklar götürülmüştür. Bkz. Schreiner, a.g.e., s. 111-113.

$47 \quad$ Schreiner, a.g.e., s. 117. 
geniş çaplı bir operasyona hazırlanmaktadır. İki Amerikalı muhabir gelecek günlerden korkmakta ve Pera'da olmak istemektedirler. ${ }^{48}$ 12/13 Mart gecesi beklentilerini haklı çıkarır. Yağmurlu gecede muşambaları altındaki askerler görevleri başındadır ve arama ışıkları Erenköy Körfezi'ni taramaktadır. Aniden projektör ışıklarından biri Çanakkale geçidi yakınındaki bir noktaya sabitlenir, ardından o noktadan alevler yükselir. Erenköy körfezine büyük bir mayın süpürme filosu gönderme hazırlığındaki itilaf donanması arama ışıklarını bombalamak için gece görevine çıkmışırı. ${ }^{49}$ Türk topçusu ile itilaf gemileri arasında karşılıklı ateş başlar. Schreiner bir Türk obüs bataryasının ateşinin arama ışıları altında denizden yükselttiği şeffaf su kolonlarını görür. Ama İngiliz destroyeri yılmaz. Burnunu Erenköy sularının karşısına çevirir ve gece dürbününün görüş menziline girer. Türk arama ışılları geminin gövdesini bacaları, direkleri, kuleleri ve silah namlularına kadar aydınlatır. Gemiden Türk projektörlerine doğru seri atış yapılmaktadır. Schreiner genellikle 11:00'de başlayıp şafakta sona eren bu gibi girişimler için müttefiklerin çoğu zaman komşu adalardan tayfaları Yunan yelkenli tekneler kullandıklarını bildirir. Bir önceki gece bunlardan biraz fazla kuzeyde seyreden birinin yelkenleri arama ışığına yakalanmış ve etrafına mermiler düşmeye başlamıştır. Kaptan gemiyi kontrolde tutmayı başarır ama mayına çarparak batmasına mali olamaz. Ardından üç buharlı mayın temizleme gemisi daha Türk topçu ateşi tarafından batırılır. İtilaf donanmasına pahalıya mal olan bu gecenin ertesi gece müttefik mayın temizleme filosu bütün gücüyle ve ağır gök gürültüsü ile yağmur altında gelir ve bir süre Menderes Nehri ağzında durur. İçlerinden bir kruvazör ilerleyerek Türk projektörlerini bombalamaya başlar. Gemi ve batarya arasındaki çatışma sonunda mayın temizleme girişimi bir kere daha başarısızlığa uğrar. Schreiner o vakte kadar müttefiklerin geçidi temizlemek için beş ciddi girişimde bulunduklarını, hiçbirinin başarıya ulaşamadığını, az miktarda mayın ele geçirilebildiğini ama onların yerine de Türklerin Ruslar tarafından Boğaziçi'nin girişine yakın kasten konulduktan sonra Boğaziçi'ne süzülen Rus mayınlarını yerleştirdiklerini yazar. ${ }^{50}$

16 Mart'ta bir grup Osmanlı devlet adamı ve parlamenteri Çanakkale'ye gelir. Schreiner heyetin geliș maksadını henüz endişeye gerek olmadığına kendilerini ikna etmek olarak düşünür ve ziyaretçilerin Çanakkale'nin hala eski yerinde olduğunu gördüklerinde çok rahatlamış göründüklerini not eder. ${ }^{51}$

48 Schreiner, a.g.e., s. 118-119.

49 Binbaşı Nazmi Bey 12 Mart’ta günlüğüne şunları yazar: “Dört günden beri düşman Boğaz girişi içerisinde görünmemektedir. Yalnız geceleri arama-tarama ve torpido gemisiyle hatlara sokulmak istiyor." Bkz. Mayın Grup Komutanı Binbaşı Nazmi Bey’in Günlüğüyle Çanakkale Deniz Savaşları, s. 95.

50 Schreiner, a.g.e., s. 120-123.

51 Gelenler arasında Türkiye'deki Amerikan büyükelçisi Morgenthau da vardır. Büyükelçi Dardanos, Anadolu Hamidiye, Çimenlik ve Kilitbahir bataryalarına götürülür. Gördüklerinden etkilenmiş görünmektedir. Schreiner, düşünceleri sorulan büyükelçinin Osmanlı Devleti'nin resmi tebliğlerine karşı son derece şüpheci olduğunu, kendisinin raporlarına da itimat etmediği fark eder. Morgenthau ketum bir şekilde şunları söyler: "Benim için söyleyecek çok şey yok. Kaleleri hasarsız ve vaziyeti iyi buldum. Subaylar ve askerlerin ruhu huzur ve güven içinde.” Bkz. Schreiner, a.g.e., s. 124. 


\section{Mart: Zafer Günü}

18 Mart, Çanakkale deniz savaşlarının dönüm noktasıdır. O gün savaşın şiddeti ve boyutları o raddededir ki, Schreiner ertesi gün "Hala hayattayım ve o kadar mutluyum ki ayaklarım yere basmıyor." diye yazar. ${ }^{52} \mathrm{O}$ gün itilaf filosu Boğaz'a geri gelir. İstekli oldukları, büyük bir gün olacağı, on dokuz hat savaş gemisi ile otuz kruvazör ve destroyer, torpido botlar, mayın-temizleyicilerden müteşekkil filonun heybetinden bellidir. Erenköy körfezine saat 11'de giriş yapan donanma, öğleden sonra 5'te yaralı çıarken Bouvet, Irresistible ve Ocean ile iki küçük gemiyi daha kaybetmiştir. Hat gemilerinden beşi devre dışı kalmış, süper dretnot-kruvazör Queen Elizabeth de Türk obüsleri tarafından en azından hareketsiz bırakılmıştır.

Aslında Schreiner 18 Mart sabahı rutin bir güne uyandığı zannındadır. Arkadaşları ile 11'de Saat Hisarlık Sokak'ta küçük bir kahvede buluşacaklar ve Çanakkale komutanı Cevat Paşa'yı ziyarete gideceklerdir. ${ }^{53}$ R.Swing’le birlikte kendilerine refakat

52 Schreiner, a.g.e., s. 126.

53 Schreiner'in Çanakkale Müstahkem Mevki Komutanı Cevat Paşa ile yapmak istediği görüşme, kendi ifadesiyle paşanın karargâhı için en tuhaf yeri seçmesi sebebiyle gecikmiştir. Burası yüksek bir dağın tepesine yakın küçük bir binadır. Buranın karargâh olarak seçilmesi kimilerince paşanın müdafaa ettiği boğaza her zaman serbest bir görüş sahibi olmak isteğinin bir sonucudur. Kimileri ise paşanın Almanlardan kurtulmak/uzak olmak güdüsüyle bu tercihte bulunduğu kanaatindedir. O gün güzel ilkbahar havası Schreiner'i paşanın karargâhına ziyaretten bir kere daha caydırdığında arkadaşı Swing ona üç haftadır Çanakkale'de olmalarına rağmen buranın en yetkili ismine saygılarını sunmamış olduklarını söyler ve Almanlarla çok yakın olmalarının Türk komutanların şüphe ve tepkisini çekeceğini vurgular. Schreiner, a.g.e., s. 127. Günlükte Türk ve Alman komutanlar arasında anlaşmazlıklar bulunduğu iması bundan ibaret de değildir. Schreiner 11 Mart’ta Alman General von Usedom Paşa ile Çanakkale'deki Alman subaylarla Türklerin ilişkilerini anlamak maksadıyla uzun bir mülakat yapar ve ilişkilerin sürtüşmesiz olmadığını öğrenir. Sürtüşmenin kaynağı her iki tarafın da deniz muharebelerinde gösterilmekte olan direncin ve başarının üstünde hak iddia etmeleridir. Her ne kadar von Usedom Paşa bu meseleye aldırmadığını söylese de Schreiner onun altındaki subayların daha az cömert olduğunu yazar. Von Usedom Paşa için Çanakkale'de ya da Kuzey denizinde olmanın kendisi için farklı olmadığı, vatanının hizmetinde olmaktan mutmain olan bir asker portresi çizilir. Bkz. A.g.e., s. 117. Türk ve Alman subaylar arasında anlaşmazlık gerekçesi olarak başarıda hak iddia etme sorunu "tarafsız" bir gözlemci olarak Schreiner'in günlüğüne de sirayet etmiştir. Alman sempatisini her fırsatta hissettiren Schreiner kritik karar ve başarıların altında hep Alman subaylarının imzalarının olduğu bir anlatı kaleme almış, Türk subay ve askerlerini adeta görünmez kılmıştır. Örneğin Alman deniz subayı Firle 13 Mayıs gecesinde İngiliz hat gemisi Goliath’ı adeta tek başına batıran adam olarak tanıtılır. Schreiner'e göre Çanakkale'nin dıșına çıkıp Seddülbahir'deki müttefik savaș gemilerinden birini torpilleme fikri komutanı olduğu Muavenet-i Milliye’nin teknik yetersizlikleri de düşünülüp üslerince olumlu karşılanmamıştır. Fakat genç subay ısrarlıdır, görüş mesafesinin iyice düşeceği uygun zaman nihayet gelir. Gün boyunca Kilitbahir'deki burnun altında bekleyen Muavenet-i Milliye, gece olduğunda, kıyıya yakın, Soğanlıdere'den aşağıya ilerler. Firle, itilaf filosunun bir kısmının Morto körfezinde yattığın düşünmektedir. Mayına çarpma riskini göze alarak Erenköy körfezine yönelir ve Eski Hisarlık altında bazı gemilerin ışıklarını gözler. Mortokörfezine ilerlerken üç İngiliz devriye gemisinin arasına girer. Diğer gemiler körfezde kayıtsızca duran bu geminin kendilerinden olduğu izlenimindedir. Morto körfezi istikametinde yoluna devam eden Muavenet-i Milliye, fark edildiğinde Goliath'a 300 yarda mesafededir. Goliath'a atılan üç torpido üç sağır edici infilaka yol açar. Savaş gemisi batarken yarattığı kaos ortamında Muavenet-i Milliye kaçmayı başarır. Bkz. A.g.e., s. 271-273. Bu çarpıcı başarıyı Schreiner dostu olduğunu bildirdiği Firle'nin hesabına yazarken fazla cömerttir. Oysa Muavenet-i Milliye Torpidosu'nun kumandanı “Kıdemli Yüzbaşı” Ahmet Saffet Bey'dir. Bkz. Liman vonSanders, a.g.e, s. 102. (Dipnot 8'de mütercim notu.) Liman vonSanders geminin Yüzbaşı Firle komutasında olduğunu söyler. Şu kaynakta ise Goliath'ı batırma eylemi sırasında komuta kararlarının kime ait olduğunun anlaşmazlık konusu olduğu, gemi kumandasının "Birinci Yüzbaşı" 
edecek Fuat Reşat Bey’i beklerken birden patlamalar duyulur. ${ }^{54}$ Etraftaki neredeyse bütünüyle havaya uçan ve havada parçalara bölünen ahşap evlerin çatı kiremitleri çevrelerine yağmur gibi yağmaya başlar. Bir ağacın koruyucu dalları altına sığınırlar. Bir kiremit parçası Schreiner'in sırtına isabet eder. Uzaktan koşarak gelen Fuat Reşat adeta ufalanmış sıva bulutu altında görülemez olur. Panik havasını gözlemlerken kahvecinin dükkânının kepenklerini zorladığını görür Schreiner, oysa kepenklerin bombalardan dükkânı koruması mümkün değildir. Kahveden ayrılıp Saat Kulesi'ne doğru yürürler. Bombardıman Boğaz’ın başka bölümlerine kaymıştır. Telgraf ve telefon merkezinden bilgi almak isterler ama operatörlerin de henüz bilgisi yoktur. Şehre bombalar Boğaz’n girişindeki büyük bir gemiden atılmıştır. Eski Hisarlık burnunun ardındaki dumanların çokluğu daha büyük bir tehlikenin habercisidir. Sığınak ararlar. Schreiner eski kuleye gitmeyi önerir ama bu çok riskli bulunur ve eski mendireğe gitmekte karar kilınır.

Bombardıman bütün şiddetiyle devam etmekte, bombaların çoğu uzağa düşse de, müttefiklerin bu sefer çok güçlü geldiğini hissettirmektedir. Schreiner tarihi deniz surlarına varıp dürbünle körfeze bakınca gözlerine inanamaz. Dokuz hat gemisi sayar, bunların arkalarından başkaları da gelmekte ama dumandan seçilememektedirler: "Gemi bacaları ve direklerinden bir orman"dır görünen. Schreiner gemilerin göz hizasında çelikten bir duvar teşkil ettiklerini, üst kısımlarının yoğun bir toz ve duman bulutu altına saklandığını yazar. Gemiler arasında Türk bombaları patlamakta, denizden büyük su kütleleri yükselmektedir. Schreiner Türk kale ve bataryalarındaki telaşı fark eder. Sonra hat gemilerinin körfezin ortasına yöneldiğini görür ve dokuz geminin daha görünmesiyle on sekiz gemi sayar. Swing ise on dokuz gemi sayar. Girişte Queen Elizbaeth ateş ve duman püskürtmektedir ve Amerikalı gazetecilerin refakatçisi Fuat Reşat Bey ümitsizliğini ifade eder: "Bizim bataryalar buna denk değil. Bu bizim sonumuz." Schreiner de itilaf filosunun ilk salvosunun Çanakkale boyunca

\footnotetext{
Ahmet Saffet Bey'de olduğu ama Alman subay ve mühendisleri ile birlikte çalıştığ C. Stern, Destroyer Battles / Epics of Naval Close Combat, Seaforth Publishing, Barnsley, 2008, s. 45 ve s. 52. Şu kaynakta da geminin "Süvari Yüzbașı Ahmet Bey'in idari, Alman Yüzbașı Fierle’nin teknik yönetiminde” olduğunu bildirir. Bkz. Yaşar Semiz, "Çanakkale Denizaltı Savaşı (Nisan-Mayıs 1915) / Sultanhisar ve Muâvenet-i Milliye'nin Başarıları”, Selçuk Üniversitesi Türkiyat Araştırmaları Dergisi, Sayı 9, 2001, s. 395. Schreiner'in hakkında belki de en uzun yazdığı Türk subayı İbrahim Bey ise askeri yetenekleri değil entelektüel birikimi ile öne çıkarılmıştır. 7 Mart akşamı bir Türk genel karargâh subayı olan İbrahim Bey'e misafir olurlar. Savaştan çok entelektüel meseleler üzerinde konuşurlar ve Schreiner başka subayların yanında açıkça İslam peygamberinin öğretilerini büyük ölçüde felsefe olduğunu söyleyen karargâh subayının “modern Müslüman” kimliğini vurgular. Üstelik İbrahim Bey’e göre bu, Musa'nın hukuki ve ahlaki öğretilerine nazaran zayıf bir felsefedir. Öte yandan İbrahim Bey Hz. Musa'yı bir tür "aşırmacılık" ile de suçlar, çivi yazılı tabletlerdeki son buluntuları referans göstererek onun kanunlarının Keldaniler ve Sümerlerce bilinmeyen șeyler olmadığını belirtir. Schreiner onun çok bilgili bir adam olduğunu, şark tarihini bir dizi Ermeni krallarının isimlerini sayacak kadar bildiğini, sohbetin giderek soyuta kaçtığını ve kendisinin koptuğunu yazar. Bkz. Schreiner, a.g.e., s. 115-116.
}

54 Binbaşı Nazmi Bey itilaf donanmasının 11:10'da Kilitbahir ve Anadolu'daki bütün istihkamlara ateş açtığını bildirir. Mayın Grup Komutanı Binbaşı Nazmi Bey’in Günlüğüyle Çanakkale Deniz Savaşla$r i$, s. 96. 
çeşitli noktaları vurmasını kasırgaya benzetir. Hissettiği, kasırga etkisinin neredeyse eşzamanlı olarak patlayan kırk küsur bomba tarafından üretilen amansız bir taklididir. Toprağın parçalara ayrıldığını düşünür. Bunu bir diğer salvo izler. Schreiner müttefiklerin moral etki için oynadıklarını düşünür. ${ }^{55}$

Çimenlik Kalesi ile kıyı arasındaki eğimli yola isabet eden bir bomba ile tonlarca şose gazetecilerin üzerine yağmaya başlayınca deniz surunu siper edinirler. Bu sefer bir başka bomba doğrudan önlerindeki sığ suda patlar. Burada kalamayacaklarını anlarlar. Siper üstündeki Türk subayları da onları görür ve çağırırlar. Fakat traversin arkasından hiçbir şey görünmemektedir. Schreiner olan biteni görebilmek için siper üzerindeki subaylara katılmak ister ama askerler buna o siper üzerinde ve istihkâmda çok geçmeden ölü adamlar olacağı gerekçesiyle sıcak bakmaz. Amerikalı gazeteci risk almaya hazır ve ısrarcıdır ama muhataplarını ikna edemez ve geri döner.

Bir süre sonra burada da kalamayacaklarını anlarlar. Sipere travers ile kavşak yaptığı yerde isabet eden bir bomba tonlarca toprağı etrafa dağıtır. Hemen ardından bir başka bomba tarihi sur duvarını vurur. Yarım ton ağırlığında bir kaya devrilip Swing'e bir ayak mesafeye düşer. Nereye gidebileceklerini düşünürler. Sultaniye Kalesi kulesinin sağlam surlarını o an gidebilecekleri en korunaklı yer olarak görürler. Peş peşe düşen her bomba ile ayakları altındaki toprak titrerken koşmaktadırlar. Hemen sollarındaki tarihi sura bir bombanın isabet etmesiyle birlikte bir taş yağmuruna maruz kalırlar.

55 Schreiner, a.g.e., s. 131-132. Bu moral etkinin hedefi sadece Türk askerleri değil, aynı zamanda sivil Çanakkale halkıdır. Nitekim Schreiner'in günlükleri halkın savaşa tepkisi ve savalın kent hayatına etkilerini gösterir çarpıcı tablolar içerir. 18 Mart günü şehir merkezini hedef alan ve sivil kayıplara sebep olan bombardıman hakkında Schreiner İngilizlerin bu hedefleri vurarak kent halkını dehșete düşürmeyi, şehrin sakinlerine gitmeleri zamanının geldiği mesajını vermeyi amaçladıklarını düşünür. Nitekim kısa bir süre sonra, adeta mesajın alındığını gösterircesine, adam, kadın ve çocuklardan müteşekkil büyük bir kalabalığı eşekleri, keçileri ve köpeklerinin eşliğinde Saat Kulesi Sokağı'ndan aşağı akarken görür. Hemen sonra pazar meydanına isabet eden iki bomba mültecileri etkiler. Biri bir minarenin üst kısmını şerefesine kadar koparan iki bomba daha kalabalığın paniğini artırır. Bkz. A.g.e., s. 128-130. Schreiner ve arkadaşları Eski Mendirek'te bombardımanı deniz surlarından izlerlerken, üstlerinden geçen bir düzine bomba Çimenlik kalesinin idare binası arkasındaki ilk ev dizisini biçer. Zeminler, duvarlar, kapılar, mobilyalar ve insan bedenleri havaya firlar. Sonrasındaki kısa bir sessizliği bir başka salvo takip eder. Bu da şehre büyük hasar verir. Bu sefer bombalar biraz daha yukarıdan gittiğinden vurdukları evleri göremezler fakat onların enkazını görürler ve saniyeler sonra duvarlarının çöküșünü duyarlar. Bkz. A.g.e., s. 132-133. Oradan da ayrılmak zorundadırlar. Çimenlik kalesinin ardındaki caddede yürürken gözlerine bir fırıncı dükkânı çarpar. Etrafta insanlar yoktur, sadece fırından ekmek çıkaran yaşlı ekmekçiyi görürler. O sırada arkasında ihtiyar fırıncının çalıştığı duvarda bir bomba alevi görülür, sonra kulakları sağır edici bir patlama sesi gelir, bina adeta uçar. Duman dağıldığında fırın yerinde yoktur. Schreiner, s. 138. Saat Hisarlık Sokağı'ndan aşağıya inip küçük meydana geldiklerinde yakınlarda bir başka ev havaya uçurulur. Saat Kulesi'nin bir tarafında ölü bir sivilin yattığını görürler. Şehirde kalanlar hadiselerin dehşeti ve uyandırdığı merakı aynı anda yaşamaktadır. Halktan bazı insanları cesaretle yamaç tarafında toplanmış, savaş gemisi ve kıyı bataryası arasındaki çatışmayı ilgiyle izlemektedir. Bunların itilaf topçusunun hatalı bir ateşine hedef olmaları ihtimal dâhilindedir. Nitekim arkalarına düşen bir bomba kalabalığı dağıtmaya yeter. Denizden bombardımanlar 18 Mart'ta sona erdiğinde, șehirde kolayca normala dönemez. Bombalanmış bir şehirde hayat hiç de hoş değildir, bombardımanın izleri ve kokusu her yerdedir. Schreiner şehrin sakinlerinden sadece köpekłler ve kedilerin geride kaldığını yazar. Onları da kimse beslemediğinden yakında ya göçeceklerini ya da birbirlerini yiyeceklerini düşünür. Bkz. A.g.e., s. 150. 
Temkinle dönüp bataryanın içine bakan Schreiner biraz önce kendisinin yanlarında kalmasına izin vermeyen subayların durduğu yerde bir duvarın enkazının dolduğu bir krater görür. Yakınındaki top faaliyet dışı kalmış, mühimmat vinci gitmiștir. Silahın platformu üzerindeki cansız bedenin oradan ayrılmasında ısrar eden subaylardan biri olabileceğini düşünür. Bu sırada nereden geldiğini bilmediği tepeden tırnağa ufalanmış harç ile kaplı, serseme dönmüş bir Türk askeri omzuna çarpar. Schreiner'e yaralı olmadığını söyler, avluda enkaz altında kalmış ve enkazdan kendi kendine çıkmayı başarabilmiştir. Onun doktor olup olmadığını sorar. Göğsünde ve karnında korkunç ağrılar hissetmektedir. Schreiner topallayan ve her adımında ağır ağrılar çeken adama ilk yardım istasyonunun yerini söyler. ${ }^{56}$

Gazeteciler için güvenli bir gözlem yeri bulmak zarurettir. Swing askeri hastanenin üzerinde olduğu, körfezin ve Türk bataryalarının mükemmel görülebileceği küçük tepeyi önerir. Bunun için Çimenlik bataryasına atılan bombaların da düştüğü Çimenlik'in kuzey avlusundan geçme riskini göze alırlar. Yolda cadde üzerinde bir f1rın dükkânının, meydan yakınında bir evin havaya uçuşuna şahit olurlar. Tepeye vardıklarında orada sığınak olmadığını görürler. Swing siper kazmayı önerir ama hem zaman yoktur hem de gemilerden siper kazarken görülmeleri tehlikeli sonuçlar doğurabilecektir. İki alan arasında yüksekliği iki fitten fazla olmayan küçük bir sırta rast gelir ve arkasında pozisyon alırlar. Anadolu Mecidiye bataryası hemen önlerindedir.

Bombardıman düzeni dikkatlerini çeker. Müttefik gemileri bombardımanı adeta hedeflerini eşit gözeterek eşit bir şekilde bomba dağıtmaktadır. Anadolu kıyısında İntepe'den Çanakkale'ye, Gelibolu kıyısında Soğanlıdere'nin güneyindeki yüksekliklerden Kilitbahir'e kadar her şey ateş altındadır. İtilaf donanmasının niyetinin bütün dış boğaz boyundaki Türk müdafaasını yıpratmak olduğu anlaşılmaktadır. Kulakları parçalayacak bir gürültü ile her bir Türk mevziinin içinden veya yanından toprak gayzerleri ve su sütunları yükselmektedir. Buna karşlılk Türk mevzilerinin faaliyeti pek etkisiz kalmaktadır. Erenköy ve Dardanos bataryaları birkaç el ateş etse de kısa menzilli silahlarının atışları kısa düşmektedir.

Schreiner bu hali ile "çatışma"yı kelimenin ima ettiği anlamda iki taraflı bir hadise gibi görmez. Adeta tek taraflı bir bombardımandır gördüğü. Boğazdaki otuz dokuz gemi devamlı çalışmaktadır. On dokuz hat savaş gemisinin her biri donanımı ile iki Türk kalesi kadar iyidir. Bu durumda Türklerin mevzilerini nasıl elde tutabildiklerini açıklamak kolay değildir. Schreiner Türklerin yeterince mühimmata sahip olduklarından da șüphelidir. Öte yandan mühimmatları olsa da silahları ve onları kullanacak adamlarının olmadığı zannındadır. Napolyon'un karada bir topun denizdeki on topa bedel olduğuna dair sözlerini hatırlar, haklı olup olmadığını görebilecektir. Üzerlerinden rüzgârını hissedecek kadar yakın geçen bir top mermisi yüz fit arkalarında patla-

56 Schreiner, a.g.e., s. 136. 
yınca kendilerine bir başka gözlem noktası aramayı düşünürler. Fakat boğaz boyunca ateş altına alınmayacak hiçbir yer olmadığından orada kalırlar.

İtilaf gemileri bombardımanın çok az isabet kaydettiğinin, çoğu atışlarının boşa gittiğinin farkındadır. Bu yüzden mesafeyi azaltma yoluna giderler. 01:45'te Türk bataryalarına epey yaklaşırlar, bunun Türk mevzileri üzerinde çok kötü tesiri olur. Anadolu Hamidiye tabyası korkunç bir şekilde taranmaktadır ve bombalar artık siper ve traversler üzerinde patlamaktadır. Bir toprak gayzeri diğerinin yanında yükselmektedir. Mevziin avlusu alt üst olmuş, kışla tamamen yere serilmiştir. Öte yandan gemilerin bataryalara yaklaşması aynı zamanda Türk topçusunun menziline girmeleri demektir. Dardanos, Erenköy bataryaları ile Soğanlıdere üstündeki obüs mevzileri de karşı ateşe başlar ve on dakika boyunca karşıllklı ateş devam eder.

Müttefik filosu o kadar büyük ve çatışma o derece yaygındır ki bir çift gözün olan biteni bütünüyle görebilmesi mümkün değildir. Schreiner filonun sağ kanadını, Swing merkezini, Fuat Reşat Bey de sol kanadı izlemektedir. Saat 2 civarıdır. Swinganiden "Vuruldu! Vuruldu?" diye bağırır. Fransız gemilerinden biri, Bouvet ağır darbe almıştır. Anadolu Hamidiye tabyasındaki büyük batarya ile ikincil bataryalar ateşe devam etmekte, yakına düşen bombalar sonucu geminin etrafında su sütunları yükselmektedir. Gemiye isabet eden bir bomba güverteden alev demetleri çıkartır. Bir süre sonra gemi ters döner. Schreiner'e göre ölenlerin sayısı dokuz yüz kadardır. İki tarafta da silahlar susar. Sonra Türk mevzilerinden büyük bir tezahürat duyulur: "Türkler ilk kanı içmişti ve tadını çıkarıyor görünüyorlardı."

Daha küçük gemilerden Bouvet'nin mürettebatına yardımcı olabilmek için botlar indirilir. Amerikalı muhabir geminin battığı yerde yüzen bazı koyu objelerin enkaz mı ceset mi olduğunu seçemez. Botların dışarıda uzun süre kalmamasını Bouvet'nin dokuz yüz mürettebatından ancak bir düzine adamın kurtarılabilmiş olmasına yo$\operatorname{rar}^{58}$

Bir süre sonra itilaf filosu yeniden ateșe başlar. Schreiner bu eylemi "öfkenin yoğunluğu ve iktidarsızlığını barındırıyordu." diye tarif eder. Yoğun ve seri atılan bombalar geniş bir alana düşer. Bazıları Boğaz'ın ortasına, Çanakkale ile Kilitbahir arasına; daha fazlası da Çanakkale'nin Rum ve Ermeni bölgelerine isabet eder. Saat 3’te bombardıman daha da şiddetlenir. Gemiler şimdi Türk bataryalarına daha da yakındır. Çok uzaktan bombardımanla boşa vakit harcadıklarını düşünmeye başlamışlardır. Fakat yakınlaşmaları onları da savunmasız kılmaktadır ve Türkler çok sayıda isabetli atış yaparlar. Saat 3:40'ta itilaf gemilerinin dördü kötü dövülmüş durumda ve yan yatmaktadır. Schreiner müttefiklerin canlılıklarını yitirdiklerini fark eder, cılız

57 Schreiner, a.g.e., s. 143.

58 Raymond Swing ise hatıralarında Bouvet'nin mürettebatından 639 kişinin öldüğünü yazar. Raymond Swing, a.g.e., s. 72. Çok daha geç bir tarihte yayınlandığı için bu bilginin Schreiner’inki gibi o günlerde cephedeki gözlem ve duyumlara dayanmadığı öngörülebilir. 
bir ateşe devam etmektedirler. Anadolu Hamidiye tabyasına atılan bombaların çoğu "çok yüksek” gitmektedir. Bunun anlamı bombaların çok uzağa düşmesidir. Bu şekilde Çanakkale'nin özellikle Rum ve Ermeni yerleşimleri mahvolmuştur. Saat 4'e gelindiğinde Schreiner itilaf ateşinin tamamen mühimmat israfına döndüğünü gözlemler.

Gün ışığı da zayıflayınca müttefiklerin çekilmekten başka çaresi olmayacağından Amerikalı muhabirler bulundukları yerden bir şeyler içmek için ayrılırlar. Çaydan sonra haber metinlerini yazmadan önce son bir gözlem için Çimenlik kalesine dönüp kule platformuna çıkmaya niyet ederler. Fakat avlunun enkaz dolu olmasından eski deniz suru üzerinden gözlem yapmaya karar verirler. Bazı itilaf kruvazörlerinin hasarlı hat gemilerini çektiklerini görürler. Bunlardan üçü henüz Boğaz'ın girişinden dışarı çekilmektedir. Bunun ötesinde kendi buhar gücü ile geri çekilen gemiler de halen seçilebilmektedir. Erenköy körfezinde biri Menderes'in ağzı önünde, diğeri Eski Hisarlık Burnu yanında olmak üzere iki hat gemisi durmaktadır. Biri kendi başının çaresine bakabilir görünmekte, ötekine ise bir dizi küçük tekne refakat etmektedir. Bunlar Irresistible ve Ocean gemileridir. Bir Türk gözcü subayından ilk geminin terk edilmiş, diğerininse çekicide olduğunu bilgisini alır. Terk edilen gemide hafif bir hareket olur, bacasından biraz duman çıkar ama pruvasında köpük yoktur, Türk bataryalarına doğru sürüklenmektedir. Rumeli Mecidiye bataryasından açıldığını düşündükleri bir ateşle gemi ortasından isabet alır. Bunu başka bombalar izler. Türk subaylarından gemiyi ateş altına alanın ve parçalara dilimleyenin Dardanos Kalesi olduğunu öğrenirler. Yirmi beş bombadan on altısı tam isabet etmiş, Irresistible nihayet batmıştır. Diğer gemi Ocean ise Morto körfezinde sulara gömülmüştür. ${ }^{59}$

İki Amerikalı gazeteci, 18 Mart'ta, son derece hareketli geçen günün sonunda İstanbul Oteli'ne gazetelerine haber yazmak üzere gelirler. Bombardımanın etkisi ile korkunç bir baş ağrısı çekerek yazılarını tamamlarlar ancak sansür memurlarını bulamazlar. General Mertens'in karargâhına giderler. Yazdıklarını okuturken, Schreiner Mertens Paşa ile diyaloğsunu kısa bir mülakata çevirir. Paşa o günkü parlak zafere rağmen yarın olabileceklerden umutlu değildir. Tabii ki gazetecilere yeterince açı konuşmaz ama müttefiklerin geri dönmelerinin kendileri için kötü olacağını söylemekten de geri durmaz. Gazetecilere gönderilerini hemen o gece paketlemelerini, ertesi sabah erkenden de buradan ayrılmak için hazır olmalarını tavsiye eder. ${ }^{60}$

59 Schreiner, a.g.e., s. 144-146. Schreiner 18 Mart zaferini İtilaf gemileri ile Türk bataryalarının bir çatışması olarak anlatır. Bu onun baktığı noktalardan anlaşılabilir bir açıklamadır. Doğrudan gözlemleyemediği unsurlar doğal olarak göz ardı edilir. Örneğin 18 Mart zaferinin belki de en önemli faktörü olan mayınlardan söz edilmez.

60 Amerikan büyükelçisi Henry Morgenthau da anılarında bu görüşmeden bahseder ve neredeyse tamamen Schreiner'in anlatımını tekrarlar. 18 Mart yani deniz zaferi gecesinde Mertens Amerikalı muhabire genel görünümün müdafaa için cesaret kırıcı olduğunu, İngilizlerin sabah erkenden geri dönmelerini beklediğini, üstelik bunu yaparlarsa birkaç saat daha dayanabileceklerini söylemiştir. Bkz. Henry Morgenthau, Ambassador Morgenthau's Story, Double Day, Page \& Company, New York, 1919, s. 225. 
O gece 01:00'e kadar yemek yeme firsatı bile bulamayan iki gazeteci ertesi sabah ilk iş otellerinin önündeki bir mendirekten boğazın girişinde göz gezdirirler ama itilaf gemileri görünmemektedir. Saat 08:00'de Çimenlik kalesine gittiklerinde de tehlike bayrağı çekilmemiş olduğunu görürler. Öğleden sonraya kadar sürekli denizi gözlerler. Beklentileri boşadır ama vazgeçmezler. İtilaf gemilerinin ertesi gün gelebileceklerini düşünürler. Türkler de bu beklentidedir. Bu yüzden boğaz boyunca her siper ve travers tamamen aşılmaz olmak için ilave 10 fit kum ile kaplanır.

Schreiner ve Swing'in Türk mevzilerini turlayarak geçirdikleri sonraki günlerde de ufukta itilaf donanması görülmez. Hasar tespiti yaparlar. Son bombardımanın bıraktığı hasarı beklediklerinden büyük bulurlar. ${ }^{61} 23$ Türk ve Alman ölmüss, 78’i de yaralanmıștır. ${ }^{62}$ Bunların çoğu da sivillerdir. Müttefiklerin bombardımanda kullandıkları silahlarını düşününce ( 6 inçten büyük 276 silah kullanıp 8 bin 500'den fazla 6 inçten büyük bomba atmışlar.) Schreiner bu sayıyı yüksek bulmaz.

Takip edilen günlerde Boğaz savunması tahkim edilir. Her gün Erenköy istikametinde ve Soğanlıdere'ye doğru araba ile Çanakkale'ye yeni silahlar ve silahlarla birlikte daha fazla mühimmat gelmektedir. Schreiner bu silahların Edirne'den geldiğini öğrenir ve Türklerin bunu ancak Bulgarlardan emin olarak yapabileceklerini düşünür. Haksız değildir. ${ }^{63}$ Müttefiklerse Çanakkale taarruzuna devam etmemektedir. Gemileri muhabirlerin bilmediği bölgelere gitmiştir ancak birkaç daha yaşlı gemi burada kalmıştır yani tamamen bir çekilmiş de değildir söz konusu olan. Nitekim 28 Mart günü bu gemiler boğazın girişine gelerek Kumkale arkasındaki yüksekliklere ateş açmışlardır. ${ }^{64}$

61 Dardanos kalesinde 1 numaralı tarette küçük bir göçük vardır. Cephanenin yanındaki 3 numaralı taret bir bomba parçası tarafından vurulmuştur, bunun sonucunda silah kaldırılamamakta ve indirilememektedir. Kısmen tamir edilir. Zemine yakın 5 numaralı taret hafif hasarlıdır. Rumeli Mecidiye tabyasında iki top geçici olarak hizmet dışı kalmıștır. Rumeli Hamidiye'de bir top bozulmuştur. Çimenlik kalesinde de bir top kaybedilmiştir. Oradaki kazamatlardan/siper biri yıkılmıștır. Anadolu Hamidiye'de bir 35,5 cm'lik top demirleme yerinden kopmuş, arabası da kötü parçalanmıştır. Yine burada bir kazamat göçmüştür. Bkz. Schreiner, a.g.e., s. 149.

62 Türk resmi kayıtlarına göre 18 Mart 1915 günü Türk kayıpları șehit ve yaralı olarak toplam 79, Alman kayıpları da ölü ve yaralı olarak toplam 18'dir. Bkz. Ahmet Esenkaya, "Çanakkale Cephesi'nde 19 Mart-24 Nisan 1915 Günleri”, Çanakkale Araştırmaları Türk Yıllığı, Yıl 11, Sayı 14, Bahar 2013, s. 51. Yani Schreiner'in günlüğüne sıcağı sıcağına düștüğü sayılara yakın rakamlar söz konusudur.

63 Mühimmat sorunun tamamen çözülmesinde en önemli adım Bulgaristan'ın ittifak devletleri yanında savaşa girmesi ve Osmanlı Devleti ile Almanya arasında kara ulaşımının tesis edilebilmesidir. Schreiner bu uğurda Türkiye'nin Ağustos ayında Bulgarlar lehine bir sınır düzeltmesini kabul ettiklerini, Eylül ayında düzeltmenin gerçekten yapıldığını ve iki hafta sonra da Bulgaristan'ın İttifak devletleri bloğuna katıldığını yazar. Bunun sonucunda Kasım ayında Türkler için ilk Alman silahları ve büyük mühimmat sevkiyatı Tuna'dan güneye hareket etmiştir. Çok fazla savaş malzemesi ve çok sayıda takviyenin Almanya ve Avusturya-Macaristan'dan Türkiye'ye akıtılması mühimmat sorununu çözmüş ve Schreiner'e göre bu sayede itilaf güçleri sonunda Gelibolu'dan çekilmeye karar vermişlerdir. Schreiner, a.g.e., s. 8.

64 Schreiner'e göre Osmanlı 11. Tümen kamplarından biri hedef alınmıș olabilse de bu en iyi ihtimalle bir gösteriden fazlası değildir. Bkz. Schreiner, a.g.e., s. 150. 
Gerek Çanakkale'de, gerekse başkentte başlıca merak ve tartışma konusu müttefiklerin bir sonraki hamlesinin ne olacağıdır. İstanbul müttefiklerin bundan sonra Gelibolu'ya çıkarma yapacağını düşünmektedir. Bu amaçla askeri birliklerin toplandığına dair söylentiler başkentte dolaşmaktadır. Mısır'a, Kıbrıs'a, Malta'ya Avustralyalı askerler getirilmiştir. Schreiner Gökçeada'nın bile bir kamp yeri olduğunu duyar. ${ }^{65}$ Türkler hazırlık yapmaktadır. Türkiye'deki Alman askeri misyonunun başı Liman von Sanders Paşa Beşinci Ordu Komutanlığına getirilmiş ve 26 Mart'ta Gelibolu'ya gelerek hazırlıklarına başlamıştır. Kara çıkarması beklenmekte, deniz savaşı bitmiş görünmektedir. Bu Schreiner ve arkadaşı Swing için Çanakkale günlerinin şimdilik bitmesi anlamına gelmektedir.

İtilaf tehdidi sona ermiş değildir ve Osmanlı başkenti de bunun bilincindedir. 18 Mart'ta arşiv ve hazinenin trenle Anadolu'ya nakli için hazırlıkla yapılmıştır. İtilaf donanmasının durdurulması ile bazı kayıtlar Haydarpaşa'da bir yük vagonuna alınmıştır. Sonraki günlerde Çanakkale'de olduğu gibi İstanbul'da da beklenti itilaf filosunun Çanakkale sahil bataryalarına yeni bir saldırı düzenlemesidir. Ama günler geçtikçe bu beklenti boşa çıkar.

Schreiner'e göre itilaf kumandanı Türk mevzilerinin ve mühimmatının durumunun ${ }^{66}$ farkına varsaydı, 18 Mart'tan sonra tekrar geri dönüp misyonunu tamamlardı. Osmanlı ordusu ve donanma liderlerinin beklentisi bu yöndeydi. İtilaf donanmasının geri dönüp Çanakkale'yi yine zorlayacağına dair bu kanaatin kaynağ taryalarındaki mühimmat yetersizliğinin itilaf filosu kumandanlarınca bilindiği inancıdır. Bu yeterince makuldür çünkü Osmanlı sahil savunma sisteminin idaresi uzun zaman Türkiye'deki İngiliz Donanma Komisyonu'nun elinde olmuştur ve komisyon-

65 Liman vonSanders anılarında Mart ayında itilaf devletlerinin karadan taarruz için hazırlıklar yaptığına dair Atina, Sofya ve Bükreş üzerinden çelişkili bilgiler geldiğini; bunun üzerine 24 Mart'ta Enver'in Çanakkale'nin savunması için özel bỉ ordu (Beşinci Ordu) kurulmasına karar verdiğini, Amiral vonUsedom'un ise böyle büyük bir çıkarma hareketine hala ihtimal vermediğini yazar. Bkz. Liman vonSanders, a.g.e., s.79.

66 Carl Mühlmann 18 Mart ertesinde Türk tarafının mühimmat durumu hakkında şunları yazmaktadır: "Orta çapta obüsler ve mayın engeli bataryaları cephane stoklarının yarısını tüketmiștiler. Kale topçusunun durumu daha da kötüydü. Topçu muharebesi için en önemli olan beş adet 35,5 cm'lik toplar, bundan sonra ancak 271 atış yapabileceklerdi, yani beher top için 50 atış düşüyordu. On bir adet $23 \mathrm{~cm}$ 'lik toplardan beher top için ise 30-58 atımlık bir miktar kalmıșt. Uzun menzilli ağır tahrip bombaları stokunun -ki sadece onların düșman gemilerinin zırhına karșı etkileri vardl-hemen hemen tamamıyla tükenmiş durumda olması endișe uyandırıcıydı... Deniz mayınlar (torpiller) için de hiçbir yedek kalmamıștı. Eğer muharebe araçları bitip tükenirse, kahramanca cesaretin ve bütün savunma sanatının ne yararı olabilirdi?" Bkz. Carl Mühlman, a.g.e., s. 67. Öte yandan şu eserde Türk ordusunun 18 Mart'ta çeşitli cins ve çapta 2 bin 250 mermi harcadığı, bunun mevcut cephanenin üçte biri olduğu, Türk topçusunun 18 Mart taarruzu gibi iki saldırıyı daha karşılayabilecek cephaneye sahip olduğu bildirilmektedir. Bkz. Muzaffer Albayrak-Tuncay Yllmazer, Sorularla Çanakkale Muharebeleri I, Yeditepe Yay., İstanbul, 2007, s. 42-43. Schreiner Türklerin mühimmat ihtiyacının ne kadar umutsuz olduğunu göstermek maksadıyla şu bilgiyi nakleder. Kuşatmanın erken evrelerinde Almanlar Trieste'den İzmir'e bir denizaltı yük gemisi vasıtasıyla mühimmat ulaştırmak için bir girișimde bulunmuşlardır. Gemi özellikle bu iş için imal edilmiş, uygun derinlikte yüzen bir tür tank/ depo olarak tasarlanmıștır. Kendinden bir güç saikine sahip değildir, kendi kendine ne yükselebilir ne de batabilir. Bu eğreti tasarım ve girişim başarısız olmuştur. Bkz. Schreiner,a.g.e., s. 152-156. 
daki İngiliz topçuluk uzmanları boğaz boyunca ne kadar mühimmat olduğundan haberdardırlar. Hatta mühimmatın önemli bir kısmını da bizzat bu komisyon satın almıştır. Schreiner'e göre İtilaf yanılgısının bir tek açıklaması olabilir: İtilaf hükümetlerinin Balkanlardaki aşırı gayretli "istihbarat" adamları tarafından aldatılması. Bu ajanlar Türkiye'ye gönderildiği iddia edilen mühimmat hususunda abartıya kaçmış olabilirlerdi. Bazı kaçak savaş malzemelerinin Romanya ve Bulgaristan üzerinden geçmiş olması mümkünse de Almanya’nın Çanakkale'ye "mavi başlıklı" mermiler ya da her sinıftan büyük bombalar getirmeyi başardığı doğru değildi. Amerikalı muhabir, 1914-15 kışında bulunduğu Bükreş'te, Türkiye'ye Romanya üzerinden mühimmat gittiği iddiasıyla meşgul olmuş ve bu konuda hükümetten güvence almıştır. İtilaf yanlısı Romen Başbakan Bratianu'nun birinci sekreteri Jonescu itilaf devletlerinin protestolarının kendilerini göstermek için aşırı gayretli istihbarat ajanları tarafından yapılan asılsız haberlerden başka hiçbir şeye dayanmadığını söylemiştir. Romanya ise olağan şüphelidir çünkü Sırplar hala Tuna ve Sava hatlarını tutmaktadır. Otranto boğazında büyük bir itilaf filosu Adriyatik denizini kapalı tuttuğundan Avusturya gemileri Osmanlı İmparatorluğu'nun herhangi bir parçasına ulaşamaz. Alman filosu zaten Akdeniz'e çıkamaz. Rusya da Türkiye'ye tüm diğer erişim yolları üstüne barikat kurmuştur. Öte yandan Schreiner Almanlar gerçekten binlerce mermiyi Boğaza nakletmeyi başarmış iseler Çanakkale'yi geçebilmek uğruna kaç geminin daha feda edilmesi gerekeceğini kimsenin bilemeyeceğini de söyler. İtilaf filosu savaşın başında bu kadar büyük bir riski göze almamıştır.

Schreiner arkadaşı Swing ile birlikte İstanbul'a 6 knotluk bir tekne ileve üç gün süren bir yolculuktan sonra döner. Kendi küçük çevrelerinde saygınlıkları artmıștır. 7 Nisan'da Sultan V. Mehmet Reşad'ın huzuruna kabul edilirler. Kabulden önce görüştükleri padişah yaveri Salih Paşa da, bizzat V. Mehmed Reşad da iki yabancı gazetecinin Çanakkale izlenimlerine büyük alaka gösterir. Schreiner, bunun basit bir bilgi talebi olmaktan öte padişahın kendisine gelmiş olan bilgileri teyit maksatlı olduğunu hisseder. Sahil bataryalarının kayıplarının azlığına dair sözlerini padişah şaşkınlıkla karşılar. Askerlerinin görkemli müdafaaları üzerine Schreiner'in sözlerine padişah mealen şöyle mukabele eder:

“Bunun için Allah'a şükrediyorum ve onlara (asker ve subaylara) müteşekkirim. Osmanlının ruhu ölmüş değil, halkım artık bir zamanlar olduğu gibi değilse de. Birçok savaşlardan geçti, çokfazla kan akıttı, fakat uzun bir barışın da günü gelecek. Osmanl milleti yeniden ileri adım atacak..." Padişahın savaşın patlak verme nedenleri üzerine de yabancı gazetecilere söyleyecek sözü vardır: "Bütün bu kan dökmenin maksadı nedir? Geridekileri dul ve yetim birakmak, insan elinin böyle zahmetle yaptıklarını böyle tahrip etmek... Ben bu savaşı istemedim. Allah şahidim olsun! Benim insanlarım da istemedi, eminim. Bu şartlar altında ne ya- 
pabiliriz, yiğitçe mücadele etmekten başka. Benim ordumun yaptığı ve yapmaya devam edeceği şey budur."67

\section{İkinci Așama: Kara Savașları}

İtilaf Devletleri donanmasının Çanakkale Boğazı'ndan geçerek başkente ulaşmak fikri Türk sahil savunma sistemi tarafından engellenince, müttefikler bu savunmayı çökertmek maksadıyla 18 Mart yenilgisinden sonra kısa bir hazırlık devresini müteakip kara savaşlarını başlatırlar. 25 Nisan'da Fransız çıkarması ile başlayan kara savaşlarının bu ilk devresini Schreiner günlüklerinde özet olarak anlatır. Çatışmaların yoğunlaştığı bir dönemde, önce Temmuz sonra Ağustos ayında iki kez Gelibolu’ya gitme fırsatı bulur ve savaşın bu devresini birinci elden gözlemleri ile günlüklerine yazar. Schreiner'in kara savaşları ile ilgili izlenimlerini günlüğünün bu izlenimlere ayrılan sayfalarına verdiği başlık çok özlü ifade eder. Gelibolu’yu cehenneme benzeterek, "Hell"ipoli der. ${ }^{68}$

Schreiner'e göre itilaf devletlerinin kara savaşlarındaki stratejisi şöyledir: İtilaf askerleri Seddülbahire Atçıbaba dağını ve komşu tepeleri almak maksadı ile çıkarlar. Böylece buraya konuşlanan ağır topçu Tepeli, Erenköy, Dardanos, Anadolu Hamidiye, Çimenlik, Mecidiye Kalesi ve Kilitbahir'deki Çanakkale kıyı savunma istihkâmlarını susturabilecek, Türklerin mobil obüs bataryalarını da kontrol edecek ve itilaf piyadelerinin yarımada boyunca ilerlemelerini kolaylaştıracaktır. Arıburnu'na yapılan çıkarmada da benzer hedefler güdülür. İngiliz askerleri Kocaçimen dağını ele geçirip sırtlara ağır topçu konuşlandırarak Anadolu Hamidiye ve Çimenlik istihkâmlarını susturacak, Kilitbahir ile Eceabat körfezi boyunca Mecidiye, Nara ve bir iki küçük mevziyi ateșe tutacak, belki Akbaş dâhil olmak üzere körfezin kuzeyini de kontrol edecekti. Gelibolu'ya çıkan birlikler başkente bir kara operasyonunu başarmak için yeterince güçlü olmadıklarından Schreiner İstanbul'u düşürmek için Kocaçimen dağının düşmesini zaruri görür. ${ }^{69}$

Schreiner İngiliz ve Fransız hükümetlerinin Osmanlı başkentine karadan ulaşmak planını yeterince iyi hazırlanmış bir plan olarak görmez. İtilaf birliklerinin Saros körfezine çıkarma yapmaları durumunda İstanbul'a ilerlemek için savaşırken Çatalca istihkâmlarını almak zorunda kalacaklarını ve bunun da kolay olmadığını söyler. Öte yandan bu harekâtın başarılı olmasının savaşın Balkanlardaki gidişatı açısından önemli olduğunu, böyle bir durumda Bulgaristan'ın ittifak devletleri safında savaşa dâhil olmayacağını, hatta itilafla birlikte hareket edeceğini belirtir. ${ }^{70}$

67 Schreiner, a.g.e.,s. 166 ve s. 168.

68 Schreiner, a.g.e.,s. 281.

69 Schreiner, a.g.e.,s. 311-312.

70 Schreiner, a.g.e.,s. 4. Çanakkale Savaşı sürerken, Bulgaristan’ın uzun bir süre İttifak devletleri ile bağının koparılmış ve atıl bırakılmıș olması, genel başarısızlığa karşın harekâtın en önemli kazanımı 
Schreiner 19 Temmuz'da günlüğüne itilaf birliklerinin gücüne ilişkin güvenilir bulmasa da bazı rakamlar not eder. Buna göre Seddülbahir'deki kuvvet 110 bin İngiliz ve İngiliz sömürge askeri ile 70 bin Fransız ve Fransız sömürge askerinden müteşekkildir. Büyük oranda Anzaklardan yani Avustralya ve Yeni Zelanda birliklerinden oluşan Arıburnu'ndaki kuvvetlerin mevcudu ise 90 bin olarak tahmin edilmektedir. ${ }^{71}$

Fransızlar önce Kumkale'de çıkarma yaparlar. Schreiner bunun bir aldatmaca olduğuna dair söylentileri nakleder. Fransızların sahili ve köyün bir kısmını kontrol ettikten sonra geri çekildiklerini bildirir. ${ }^{72}$ İngilizler ise Gelibolu'nun güney ve batı kıyısında Eski Hisar, Seddülbahir, Helles Burnu, Kumtepe, Zığındere, Kabatepe ve Arıburnu gibi birçok noktada karaya çıkar. Karaya çıkan birliklere itilaf gemileri de etkin bir şekilde destek verir. Yine de çıkarmalar güçlükle ilerler, müttefiklerin sahilde ve daha yukarıdaki mevkilerde tutunmaları kolay olmaz. Schreiner Türk müdafaasını anlatırken şöyle der: "Türk piyadesi görülmemiş bir cesaret ile savaştı. Ama sonunda yol vermek zorunda kaldı. Daha iyi pozisyonlara çekildi ve vahşi bir pozisyon savaşı takip edildi." ${ }^{73}$

Çanakkale'deki deniz savaşlarının ertesinde İstanbul'a giden Schreiner imparatorluğun doğu ve güney vilayetlerine seyahatinden mayıs ayı sonunda döner. Arkadaşı Raymond Swing de bu dönemi Balkanlarda seyahat ve izlenimle geçirmiştir. Gelibolu'da kara savaşı devam etmektedir ancak iki gazetecinin bölgeye gidebilmeleri ancak Temmuz ayında mümkün olabilir. Deniz yolunun emniyetsiz olmasi ${ }^{74}$ ve

olarak Asquith, Churchill gibi İtilaf devlet adamlarının resmi beyan ve raporlarında da ifade edilmiştir. Bkz. Selçuk Duman, "Hüsameddin Bey’in Çevirilerine Göre Çanakkale Savaşları", Türklük Bilimi Araştırmaları Dergisi, Sayı XXXIII, Bahar 2013, s. 141.

71 Schreiner, a.g.e.,s. 312.

72 Bursalı Mehmet Nihat 25 Nisan sabahı çıkarma yapan Fransız birliklerinin gün boyu serbest kalmalarını 15. Kolordunun Alman kumandanına bağlar. 25-26 Nisan gecesi ve 26 Nisan sabahı ise Türk kuvvetleri Fransız müfrezesine saldırmış, Kumkale'ye girilmiş ve o günün akşamı Fransızlar gece karanlığından istifade ederek ve önemli de kayıp vererek çekilmişti. Bursalı Mehmet Nihat, a.g.e., s. 21.

73 Schreiner, a.g.e.,s. 281. Kara savaşları başladığında müttefiklerin ateş üstünlüğü yeniden ortaya çıkar. Karaya çıkan birliklere itilaf donanması da topçu desteği verir. Bu yüzden çıkarmanın ilk dört gününde itilaf birlikleri ciddi aşama kaydederler. İşgal ettikleri yerlere bir miktar ağır ve hafif topçu yerleştirseler de itilaf kuvvetleri daha fazla ilerleme kaydedemez. Çatışma bir siper savaşına dönüşür. Siperler birbirine oldukça yakın, aralarındaki mesafe kısadır. Bu yüzden itilaf gemilerinin ateşi itilaf piyadesi için de tehlike arz etmektedir. Bu durum müttefiklerin ateş üstünlügünü azaltmaktadır. Öte yandan, sahip oldukları teknolojik üstünlüğe rağmen itilaf güçleri Türk lojistik sistemine de zarar veremezler. Çünkü Türkler coğrafi yapıyı lehlerine kullanmakta, güney arazisine çoğunlukla derin vadiler ve kanyonlar üzerinden yaklaşmaktadırlar. Arıburnu'nda cephe yakınına geceleri nakliyat yapılabilmektedir. Schreiner,a.g.e., s. 313. Bölgenin coğrafi yapısının savaşın gidişatına tesiri hakkında bir yorum için bkz. Ali Uzun, "Çanakkale Savaş Alanının Coğrafi Özellikleri ve Bazı Doğa Olaylarının Savaşın Kaderine Etkisi”, Gelibolu / Tarih, Efsane ve Anı (Ed: İ. G. Yumuşak-M. İlhan, İstanbul Medeniyet Üniversitesi, İstanbul, 2013, s. 137-144.

74 I. Dünya Savaşı'nda denizaltıların en önemli işlevi bir ulaşım ve nakliye sahası olarak deniz yollarının güvensizleştirilmesidir. Çanakkale Savaşı́nda da denizaltılar bu işlevleri ile öne çıkmışlardır. Çanakkale'den geçebilen İngiliz denizaltılarının faaliyetleri Marmara denizini güvensiz bir bölge haline getirmiştir. Schreiner Türklerin başlangıçta haftada bir ya da iki gemi kaybettiklerini, ancak çok 
Swing’in denizyolu ile Akbaş’a gitme denemesinin bir İngiliz denizaltısı tarafından tehlikeli bir biçimde akamete uğratılmış olması ${ }^{75}$ dolayısıyla Gelibolu'ya karadan gitmeyi planlarlar.

İki Amerikalı gazeteci 10 Temmuz'da demiryolu ile Uzunköprü’ye gelirler. Ertesi gün bir otomobilin kendilerini Liman von Sanders'in Yalova'daki karargâhına götürmesini beklerler. Ancak sabah aşırı yüklü bir motorlu yük taşıtı gelir. ${ }^{76} \mathrm{Bu}$ aracın motoru arızalanınca bagajları için komşu köyden iki manda arabası kiralarlar ve Keşan'a doğru zor şartlarda hareket ederler. Bagajları oldukça ağırdır: Çadır, alan yatağı, portatif mutfak ve tuvalet ekipmanı, 300 poundluk erzak, kişisel eşyalar, kağıt ve karbon levha ile kalemler, haritalar, dürbünler, tıbbi malzemeler, bandajlar, pire tozu, kolonya, kamera, kimlik bilgileri...

Akşamüstü saat 06:00'da başlayan yolculuklarında saat 10:00'da Keşan'ın 1şıklarını görürler. Keşan hala Balkan Savaşı’nda Bulgar işgalinin izlerini taşımaktadır, evlerin üçte ikisi yıkılmış ve nüfusun üçte ikisi başka bölgelere gitmiştir. Ertesi gün bir at arabasıyla Keşan'dan ayrılırlar. Arabada kendileri ile birlikte iki de subay vardır. Hava sıcak ve tozludur. Kurudağ'dan geçerken, Saros kıyısı yakınında, günbatımı sonrasında Bolayır'da bölgede trafiği kontrol etmek üzere devriye gezen bir İngiliz kruvazörünü fark ederler. Gece 11:00'de vardıkları Bolayır'da kendilerini bombalanmış bir şehir manzarası karşılar. Oldukça yakın zamanda Rus zırhlı kruvazörü Askold tarafından bombalanan şehirde hasar görmedik bir tek ev kalmamıştır. Bombalanan yerler arasında Osmanlı tarihi açısından sembolik önemi haiz Süleyman Paşa Türbesi ve modern Türk düşünce ve edebiyatının mühim ismi Namık Kemal'in mezarı da vardır. Bomba düşen mezarlardan saçılan ceset kalıntıları toplanıp bir başka yere

geçmeden bu sayının dört ila altıya çıktığını yazar. Savaş şartları dolayısıyla zaten gemi nakliyesi biraz kısıtlanmıştır. Yeni gemiler temin etmenin de yine savaş şartları dolayısıyla mümkün olmaması sorunu daha da çözümsüz kılmıștır. Marmara denizinde yol emniyeti o kadar tehdit altındadır ki Schreiner arkadaşı Raymond Swing'in denizyolu ile Gelibolu'ya gitme teșebbüsünü anlatırken bunun için Türk makamları ile birlikte İngiliz donanmasından da izin almak gerektiğini söyler. Schreiner, a.g.e., s. 252. İtilaf denizaltılarından duyulan korku Schreiner ve Swing'in aslında çok daha erken bir tarihte, 28 Şubat'ta, Çanakkale'ye daha ilk yolculukları sırasında şahit oldukları bir korkudur. Kendilerini Çanakkale'ye götüren Peyk-i Şevket muhribinde dört denizci denizaltı gözlemek üzere konuşlandırılmıştı. Schreiner, a.g.e., s. 68.

75 R. Swing'in Akbaş'a gitmek üzere bindiği tekne Marmara Adası yakınlarında bir İngiliz denizaltısı tarafından durdurulur. Denizaltı komutanı gemidekileri sorguya çektikten ve gemidekilerin asker olmadıklarını anladıktan sonra kaptana yolcularının gemiden ayrılmak için on dakikaları olduğunu bildirir. Yolcular botlara inerler, tekne batıılır. Ekipmanlarını da kaybeden Swing kürek çekerek Tekirdağ'a ulaşır ancak pasaportu Akbaş için yazılmış olduğundan orada karaya çıkmakta da zorluk yaşar. Tekirdağ'dan araba ile Muratlı'ya, oradan da trenle İstanbul'a döner. Schreiner, a.g.e, s. 253-256. Hadisenin Swing'in ağzından ayrıntılı bir anlatımı için bkz. Raymond Swing, a.g.e.,s. 92-102.

76 Uzunköprü Gelibolu’yu savunan Beşinci Ordu'ya en yakın demiryolu istasyonudur. Ordu komutanı Liman von Sanders anılarında Uzunköprü'nün yedi günlük mesafe olduğunu, nakliye araçlarının ise çok sınırlı olduğunu, o tarihte Osmanlı ordularında henüz kamyonlar bulunmadığını, öküz arabalarının ise büyük zorlukla günde birkaç ton yük taşıyabildiğini yazar. Liman von Sanders, a.g.e., s. 98. Bu şartlar altında Schreiner ve yol arkadaşlarına motorlu taşıt tahsis edilmiş olması onların misyonuna verilen ehemmiyeti de gösterir. 
gömülmüștür. Schreiner, savunmasız bir kasabayı bombalamanın bir bataryayı bombalamaktan farklı olduğunu yazar ve bu fili kınar. ${ }^{77}$

13 Temmuz'da Gelibolu'dadırlar. Şehirde bombardımanın izleri hemen gözlerine çarpar. Bomba isabet eden binalar arasında hastane de vardır. Denizaltı korkusuna rağmen kiraladıkları bir mavna ile Gelibolu'daki Osmanlı kuvvetlerinin lojistik merkezi Akbaş'a ulaşırlar. Yüzlerce deve ve manda kervanları, binlerce hamal, binlerce ton her türden askeri malzemenin sürekli hareket halinde olduğu Akbaş'ta, Amerikalı gazetecileri karargâhı Yalova köyü yakınında bulunan Feldmareșal Liman von Sanders'in kurmay başkanı Binbaşı Prigge karşılar. Yalova köyü bombalanmış, sakinleri köyü terk etmiştir. Birçok evler çökmüş, bahçeler ve bağlar ihmal edilmiştir. ${ }^{78}$

Karargahtaki ilk gecelerinin sabahında saat 06:25'te bir bombardımanla uyanırlar. Kaldıkları çadıra bomba ya da kaya parçaları isabet eder. Hızla vadiye koşarlar. Bombardıman bittiğinde saat 07:30'dur ve herhangi bir can kaybı olmamıștır. Schreiner bunu bombardımanda kullanılan mühimmatın niteliksizliğine bağlar. Mermiler kısa gitmekte, çoğunlukla hedef aldığı yamacın dibindeki çayıra düşmektedir. Yine de "arazinin hiçbir metrekaresinin günde tek bir saniye için güvenli olmadiğı"nı not eder. $^{79}$

Ertesi sabah bombardımana uyanmazlar ama sabah, öğlen ve akşam üç kez itilaf uçak filosunu görürler. ${ }^{80}$ Yirmi kadar uçaktan müteşekkil filonun amacı günde üç kez Akbaş üzerinde uçarak buradaki tedarik mekanizmasını aksatmaktır. Uçaklardan zaman zaman atılan bombalardan bazıları Liman von Sanders'in karargâhına düşmektedir. Arıburnu'ndan gelip Akbaş üzerinde uçan uçaklara Türk uçaksavar ateşi cevap vermektedir. Öte yandan göğüs göğüse çarpışmalar da devam etmektedir. Arıburnu ve Seddülbahir'de gece çöktüğünde topçu bombardımanı, patlayan mayınlar, fırlatılan el bombaları ve makineli tüfek sesleri birbirine karışmakta, küçük silahlar da dağınık ateşe katılmaktadır. Ardından sahneyi birbirlerine süngü ve bıçakla saldıran askerler almaktadır. ${ }^{81}$

İki gazeteci Arıburnu'na gitmeyi tasarlamaktadır. Ne var ki yolun bir kısmı İngilizlerin atış menzili içinde kalmaktadır. Üstelik Swing hayatında hiç ata binmemiştir, yine de gelmekte ısrarcıdır. Arıburnu yolunda onlara bir Türk süvari subayı eşlik eder. Eskiköy’e kadar nispeten rahat bir yolculuk yaptıktan sonra hızlanırlar. Bir ara

77 Schreiner, a.g.e.,s. 286.

78 Schreiner, a.g.e.,s. 293-294.

79 Schreiner, a.g.e.,s. 291.

80 Schreiner Mart ayında deniz savaşlarını izlerken de İtilaf uçaklarının faaliyetine şahit olmuştur ama o zaman bu faaliyet haber alma işlevi ile sınırlıdır. Örneğin İtilaf gemilerinin Kilitbahir üzerine yoğunlaşan bombardımanına sahne olan 5 Mart günü saat 3:45 civarında bir itilaf uçağının Kilitbahir’i yukarıdan görüntülemek üzere süzüldüğünü yazar. Uçağın görevi bombardımanın hasarını rapor etmektir. Bkz. Schreiner, a.g.e.,s. 91.

81 Schreiner,a.g.e., s. 294. 
İngilizlerin makineli tüfek menziline girip kurşunlar arasından geçmeyi başarırlar. Arıburnu'nda onları Esat Paşa karşılar. ${ }^{82}$ Günü burada araziyi inceleyerek geçirirler, bir Türk subay onlara İngiliz mevzilerinin krokisini sunar. Birkaç gün önce bir ateşkes yapıldığını ve bu arada 4 bin küsur ölünün defnedildiğini öğrenirler. ${ }^{83} \mathrm{Ne}$ var ki alana yine çürümeye yüz tutmuş insan bedenleri saçılmıştır. Ege'den gelen esintiler karargâha bir koku dalgası getirmektedir. Öğleden sonra üç itilaf uçağının bombardımanına maruz kalırlar. Bombaların birkaçı fazlaca yakına düşmüştür.

17 Temmuz'da Schreiner bu sefer Continental Times'in Gelibolu muhabiri Bay Bleck-Schlombach ile birlikte Ali Bey Çiftliği yanında, Güney Grubu komutanı Weber Paşa'nın karargâhındadır. Paşa gazetecilere bölgesinde hiçbir sır olmadığını, her yeri görebileceklerini bildirir. İncelemelerine Batı Kirte'den başlarlar. Ali Bey Çiftliği’nin batısında, bombardımanların tüm şiddetini görürler: Yan yana kraterler ve araziye kaya parçaları gibi serilmiş çelik parçaları. Uzun bir sipere girerler. İngiliz siperlerine paralel bir vadide ilerlerken, İngiliz tüfek ve makineli tüfek ateşine tutulurlar. Schreiner İngiliz hattından doğrudan üstlerine gelen büyük bir el bombası parçasının isabet ettiği bir Türk askerini tasvir eder. Bağırsakları elbisesindeki büyük yırtıktan dışarı çıkmak üzeredir. ${ }^{84}$

Dönüş yolunda vadi boyunca savaşın farklı manzaralarına şahit olurlar. Siper benzeri bir yerin savaş hattına bağlandığı bir yere gelirler. Uzun sedye taşıyan hastabakıcı sıraları, sedyelerde yaralılar... Öldüğü anlaşılan yaralıları daha fazla taşımanın faydasız olduğunu düşünen görevlilerin yüklerini yolun kenarındaki çimlerin üzerine bırakmaları... Schreiner yaralıların çoğunun epey sıkıntılı olduklarını ama pek azının inleyip sızlandığını söyler. Hepsi de acı verici bir çaba olmasına rağmen selam vermek zorunda hissetmektedir. Oysa "merhaba”ları pek cılızdır. Askerlerin pek çoğu kendi kıt su tedariklerini yaralılarla paylaşmaktadırlar. ${ }^{85}$

18 Temmuz daha sakin bir gündür. Schreiner Türk pozisyonlarını incelemek için Batı bölgesine geri gider. Siperleri yeterli bulmaz. Bunların yarısı eğik konumdadır ve toprak da derin değildir. Türklerin içinde bulundukları zor zaman daha fazlasına imkân da vermemiştir. Hendekler boğucu derecede sıcak ve havasız, su ise kıttır.

82 Karargâhında Amerikalı gazetecileri sıcak karşılayan Esat Paşa onları öğle yemeğinde Türk ve Amerikan bayrakları ile dekore edilmiş bir salonda ağırlar. Schreiner onu "istekli ve keyifli bir evsahibi" olarak tanımlar: "Savaş görmüş Yanya kahramanı her şeyi iyice açıklıyor ve kendi işlerinden de büyük bir tevazu ile bahsediyordu. Bütün iyi askerler gibi, rakibini hafife almıyordu, ne de onun hakkında saygılı terimlerden başkasını kullanmıyordu." Schreiner,a.g.e., s. 298.

83 İngiliz istihbarat subayı Aubrey Herbert'in 6 Temmuz 1915 tarihinde günlüğüne yazdıkları burada anlatılanlar ile örtüşen bir tanıklık olarak zikredilebilir: "Siperlerimizin üstündeki Türk ölülerini gömmek için bir ateşkes anlaşması ayarlama konusunu konuştuk. Aksi takdirde adamlarımızın koleraya yakalanacă̆ını söylediler; sıcak, kum, sinekler ve koku berbattı... " Bkz. Aubrey Herbert - Henry Morgenthau, Çanakkale / Devler Ülkesinde Devler Savaşı(Çev. Seyfi Say), Yeditepe Yay., İstanbul, 2007, s. 90.

Schreiner,a.g.e., s. 301-302. 
Askerler toprak yığını üzerinde oturmakta, vakit geçirmek için çocuklar gibi çakıl taşları ile oynamaktadır. Kimisi siperlerini geliştirmekle meşguldür, kimisi düğmeler ve yamalar üzerinde dikişle, kimisi de silahlarının temizlik ve bakımı ile.

Schreiner Akbaş’a birlikte geldikleri 9. Alay'dan M. Hadi ile görüşür. Kıdemli yüzbaşı olan M. Hadi ile kahve içerken fincanı burnunun hemen dibinde tutarak, bir süre için harp sahasının korkunç kokusunu duymamayı başarabildiğini yazar. İki dikenli tel örgü arasında yüzlerce ölü İngiliz ve Türk askerleri yatmaktadır ve geceleri bunların çok azı toprağa verilebilmektedir. ${ }^{86}$ Siperlerde sürekli bir trafik vardır, her iki yönde sürekli askerler geçmektedir. Siperin darlığı dolayısıyla karşı yönden gelenler geçene kadar siper duvarına sıkışmak ya da toprak yığınına çömelmek gerekmektedir. Schreiner siperin üzerinden baktığında tam karşısında "Spanish riders" tabir edilen ve bir tür bıçkı tezgâhına benzettiği sivri ahşap engeller görür. Bunun ötesinde Türklerin altı ila on beş metre genişliğindeki dikenli tel alanı bulunmaktadır. Dikenli telin ardında ise bir tür "tarafsız bölge" uzanmakta, onu da müttefiklerin tel örgüleri takip etmektedir. Hatlar arasında kalan alan ölü de olsa kalın ve yüksek bir ot tabakası ile kaplıdır. Schreiner burayı ölü askerlerin içinde yattıkları bir köstebek yuvasina benzetir. Dört yüz - dört yüz elli kadar ceset görür. Dürbünle incelediği yakındaki cesetler çürümektedir. Bazıları normal ebatlarının iki katı kadar şişmiştir. Yine de savaş sahneleri yaşayanlar için dehşetini yitirmektedir. Nitekim Schreiner siperlerdeki Türklerin manzarayı çok kafaya takar görünmediklerini yazar. Daha atak bazı askerlerin gece siperin üstünden geçip cesetleri aradığını ve onlardan değerli görünen șeyleri aldığını bildirir. ${ }^{87}$

19 Temmuz sabahı Weber Paşa'nın karargâhının bulunduğu vadiyi Erenköy körfezindeki müttefik gemilerden biri ateşe tutar. Vadideki mağaralar bombalara karşı sığınak işlevi görmektedir. Öğle vakti bu sefer bir hava saldırısı olur. İlk bomba bir ahıra isabet eder. Schreiner yaralanan atları, hemen sonra yaralı atların vurulmalarını görür. İki uçak üzerlerinde uçmakta, çevrelerinde daireler çizmektedir. Schreiner Weber Paşa'nın karargâhının orada olduğunu bildiklerini düşünür.

21 Temmuz'da Schreiner Yalova'dan ajansına Gelibolu'daki son durumu değerlendirir yazısını gönderir. Yazıda itilaf stratejisinin yürümediği, Türklerin cesur bir savunma ortaya koydukları fikri işlenmektedir. Türklerin en büyük sorunu mühimmat ve lojistik malzeme eksikliğidir ancak o da arazinin itilaf birliklerine çıkardığı zorluklarla azalmıştır. Schreiner şöyle bir kehanette bulunur: "Müttefikler operasyonun kış aylarına uzaması durumunda yarımadadan çekilmeye mecbur olacaktır." 8

86 "İki tarafin cepheleri arasındaki sahada kalan cesetlerin tefessühünden cepheye yakın yerlerde tahammül edilemeyecek kadar fena kokular intişar ediyordu. Havada türlü hastallk mikrobu ile dolu kesif toz bulutları eksik değildi. Müziç iri sinek sürüleri insana göz açtırmıyordu." Bkz. C. F. Aspinall Oglander, Çanakkale Muharebeleri / Ingilizlerin Gelibolu Seferinin Resmi Tarihi (Terc: Muharrem Feyzi), Kanaat Kütüphanesi, İstanbul, 1932, s. 42-43.

87 Schreiner, a.g.e.,s. 306-308.

88 Schreiner, a.g.e.,s. 313. 
Schreiner ve Swing 15 Temmuz'da ve 23 Temmuz'da Liman von Sanders Paşa ile mülakat fırsatı bulurlar. Alman komutan onlara yeterli mühimmat verildiği takdirde yarımadayı sonsuza kadar tutabileceğini söyler. Gelibolu'yu elde tutabilmenin şartı İstanbul'un kendisine daha fazla cephane sağlamasıdır. İfadeleri çarpıcıdır: "İhtiyaç duyduğum şey mühimmat, mühimmat, mühimmat ve sonra daha fazla mühimmat." Paşanın bu sözleri yabancı gazetecilere bu kadar açık ifade etmesi şaşırtıcıdır. Nihayet askeri sır sayılabilecek bir zaafı dillendirmektedir. Bu Liman von Sanders'in umurunda değildir:

"Benim burada askeri sırlarım yok. Uçaklarla ve etraftaki Rumlarla düşman bizim işlerimiz hakkında bazen bizim bildiğimizden daha fazlasını biliyor. Ben bile etrafta dolaşmak için yeterli telefon kablosuna sahip değilim..." 89

Schreiner'in Gelibolu günleri şimdilik sona ermiştir. 25 Temmuz'da deniz yolu ile İstanbul'a dönmek üzere Çanakkale'den ayrılır.9 Ağustos'ta, yani 6 Ağustos'ta General Ian Hamilton kumandasındaki İngiliz kolordusunun Arıburnu'nda Suvla Koyu'na yapılan çıkarma ile üçüncü bir cephe açmasından üç gün sonra İstanbul'da Enver Paşa ile görüşür. Paşa Amerikalı gazeteciye vaziyete hâkim olduklarını söyler ve kendinden oldukça emin görünür. Savaşın uzamasının daha fazla asker sorunu olduğunu, kendisinin iki yüz bin yedeğe sahip olduğunu ifade eder. Kazanmak zorunda olduklarını, en sonunda galip geleceklerini bildirir. Schreiner Enver Paşa'nın yanından yeniden Gelibolu'ya gitme izni ile ayrılır. ${ }^{90}$

Schreiner haklı çıkmıştır. Gelibolu'daki gelişmeler Nisan'da karaya çıkan kuvvetlerin hedeflerine ulaşamadığını ve mevcut durumda ulaşamayacağını göstermiştir. İki cephede biraz arazi kazanılmıștır ancak kalıcı bir zafer söz konusu değildir. Bunun başlıca sebepleri itilaf birliklerinin büyük ölçüde itilaf gemilerinin desteğine bağımlı olmalarıdır. Türk siperleri üzerine deniz topçusunun doğrudan ateşinin başarısı bunların itilaf siperleri ile arasındaki mesafenin geniş olmasına bağlıdır. Türklerin bunu fark etmeleri ve kendilerini düşman siperlerine daha yakın konumlandırmaları ile İngiliz donanma topçularının kendi piyade hatlarını bombalama riski ortaya çıkmıştır. İngiliz birliklerinin bu şartlarda donanmanın topçu ateşi desteği olmaksızın daha fazla ilerlemeleri mümkün değildir. Bu tabloda Gelibolu’ya ikinci bir sefer kuvvetinin getirilmesi anlaşılabilir bir durumdur. ${ }^{91}$

Ne var ki takip eden günlerde, Ağustos ayının ortalarında, Suvla Koyu'ndaki İngilizlerin konumu Arıburnu ve Seddülbahir'deki birliklerin konumuna benzemek-

89 Schreiner, a.g.e.,s. $292-293$ ve s. 315.

90 Schreiner, a.g.e.,s. 329-332.

916 Ağustos'ta başlayan İngiliz taarruzu ve Türk tarafının direncinin ayrıntılı bir anlatımı için bkz. Carl Mühlman, a.g.e., s.129 vd. 
tedir. Başlangıçta sınırlı başarılar elde edilen General Stopford'un Kocaçimen dağının zirvelerini ele geçirme çabaları başarısız olur. ${ }^{92}$ Birlikler hastalıktan daha fazla muzdarip hale gelir. ${ }^{93}$ Savaşın başında İngiliz denizaltılarının Türk nakliye araçlarına oluşturduğu tehdidin bir benzeri şimdi Alman denizaltıları tarafından itilaf gemilerine yönelmiş, ${ }^{94}$ bu da lojistik sorunlarını büyütmüştür. Ciddi bir sorun teşkil eden içme suyu eksikliği de itilaf birliklerinin Gelibolu'dan çekilmesinin sebeplerindendir. ${ }^{95}$ İlk olarak Aralık'ta Suvla koyu ve Arıburnu tahliye edilir, ardından Ocak ayında Seddülbahir terk edilir.

İtilaf devletlerinin 6 Ağustos'taki çıkarması sonrasında kara savaşlarının vaziyetini yerinde görmek üzere Schreiner çıkarmadan yaklaşık iki hafta kadar sonra yeniden yollardadır. Akbaş'a giden ve silahlı gemilerle korunan bir levazım filosu içindeki bir torpido bota biner. Marmara denizindeki İngiliz denizaltılarının yol açtığı güvenlik endişesi dolayısıyla geceleri yolculuk etmektedirler. Bu yüzden 19 Ağustos'ta

927 Ağustos'ta Suvla'ya çıkan İngiliz birlikleri ilk gün Mestantepe'yi aldıktan sonra durur. General Stopford'un General Hamilton'un karargâh subayı Aspinal'e "Evvela bol miktarda topçu müzahereti, sonra erzak ve soğuk su temin edilmeden ayağımı şuradan şuraya atmam” dediği rivayet olunur. 8 Ağustos gecesi İngiliz ileri harekâtı Tekketepe'de durdurulur. Anafartalar ve Conk Bayırı henüz 34 yașındaki Miralay Mustafa Kemal Bey idaresinde Türk zaferlerine sahne olur. Nitekim Lord Kitchener General Hamilton'a 15 Ağustos tarihli mektubunda şöyle yazmıștır: "Bu harp genç adamlar muharebesidir." Bkz. Mehmet Şevki Yazman, Bir Subayın Kaleminden 'Türk Çanakkale' / Cephaneniz Yoksa Süngünüz Var, Yeditepe Yay., İstanbul, 2008, s. 410.

93 "Haziranın ortalarında Ingiliz askerinin yalnız manevî ahvali değil, bedenî sıhhati de bundan müteessir olmağa başlamıştı. Hastaların miktarı günden güne fevkalade çoğalıyordu. Dizanteri müstevli halde idi. Bu hastalı̆̆a tutulmayan asker kalmamıştı.” Bkz. C. F. Aspinall Oglander, a.g.e., s. 43.

94 İngiliz savaş muhabiri Bartlett’in yazdıkları Alman denizaltılarının İtilaf askerlerinde yarattığı dehşeti göstermektedir: "Denizaltılar ile yakınlık hâsıl oluncaya kadar herkesin uğradığı heyecan ve telaş eserleri asla unutulacak bir hadise mahiyetinde değildir. Denizin yüzeyinde yüzen boş bisküvi kutuları, odun parçaları, bir bacağı yukarı kalkıp periskop gibi görünen at leşleri, hulasa her şey denizaltı zannolunuyordu." Bkz. Ellis Ashmead Bartlett, Çanakkale Gerçeği(Çev. Yüzbaşı Rahmi; Yay. Haz. Muzaffer Albayrak), Yeditepe Yay., İstanbul, İstanbul, 2007, s. 259. Buna karşıllı Alman denizaltılarının Türk askerinde meydana getirdiği sevinç ve güven duygusunu bir Türk subayı günlüklerinde şöyle ifade etmektedir: "3 Haziran 1915 - Sabahleyin bir Alman denizaltısı, bir iki torpido eşliğinde önümüzden geçiyordu. Artık bizdeki şenlik; mendil sallamalar, selamlar... Fotoğrafinı çektim, ufacık bir şeydi." Haydar Mehmet Alganer, Çanakkale Kara Savaşları Günlüğü, Deniz Basımevi, İstanbul, 2010, s. 44. 25 Mayıs ve 27 Mayıs'ta Triumph ve Majestic adlı İngiliz zırhlılarını batırdıktan sonra 5 Haziran'da İstanbul'a varan ve büyük coşku ile karşılanan Alman denizaltısı U-21'in komutanı Otto Hersing denizaltıların savașta oynadığı belirleyici rolü şöyle ifade eder: "Bu seferin başarısı, siyasal ve askeri alanda da etkisini gösterdi. Çanakkale önünde bir Alman denizaltısının varlığını gören düşman, bu deniz girişiminin yararsızlığının ayırdına vararak çekildi. Şimdiye değin tarafsız kalmış olan Bulgaristan'ın saflarımızda savaşa girmesine neden oldu...” Bkz. Otto Hersing, Çanakkale Denizaltı Savaşı(Çev. Bülent Erdemoğlu), Türkiye İş Bankası Kültür Yay., İstanbul, 2009, s. 53-54.

95 "Bu öyle bir muharebe idi ki anlatılan nokta ve mevkiler, harita üzerinde gösterilmiş olmaktan başka bir değeri olmayan yollar üzerinden su, erzak ve mühimmat yetiştirmek ve bu tepe ve bayırlardan aşağl, Ağustos'un bu kızgın günlerinde, yaralıları taşımak zorluk ve eziyetleri fazlasıyla mevcuttu." Ellis Ashmead Bartlett, a.g.e., s. 243-44. Aspinall Oglander de itilaf tarafında yaşanan iklim ve coğrafyadan kaynaklı zorluklar ile susuzluğu söyle tasvir eder: "Yeis ve fütur veren bu ahvale ilaveten memleketin iklimi gaddar bir düşman halini almıştı. Öğleyin güneşin harareti tahammül edilemeyecek dereceye çıkıyordu. Sığınacak gölge ya hiç yoktu, yahut pek azdı. İçecek su cihetinden dahi sıkıntı çekiliyordu. Siperlerde kavrulmakta olan askerler hararetlerini teskine kâfi su bulamıyorlardı." Bkz. C. F. Aspinall Oglander, a.g.e., s. 42. 
Tekirdağ'da karaya çıkarlar. 20 Ağustos'ta Akbaş'tadırlar. Schreiner'in ilk izlenimi k1yıda hareketliliğin çok artmış olduğudur. Yarımadadaki yeni birliklerin trafiği \% 40 artırmış olduğunu yazar. İtilaf denizaltıları, uçakları ve dolaylı ateşi kıyıdaki askerlerin görev ve sorumluluklarını ağırlaştırmıştır.

Schreiner bu gözlem gezisinde önce İtilaf ordularının en önemli hedefi olan Kocaçimen'e gider. Yerin on beş metre altında topçu gözlem istasyonunda bir gün geçirir. İtilaf topçu ateşinin istasyonun kiriş ve tahta tavanından biraz toprak akmasına sebep olmak dışında etkisi olmadığını gözlemler. 23 Ağustos sabahı, yani "Çanakkale muharebelerinin sonuncusu" ${ }^{96}$ ve aynı zamanda "en fazla askerin katıldiğı, en büyük muharebe"97olan İkinci Anafartalar Muharebesi'nden sadece iki gün sonra, İstanbul'daki Alman askeri ataşesi Albay von Lassow ile birlikte saat 07:00'de bir Türk onbaşı rehberliğinde önce Büyük Anafarta'ya sonra da Kocaçimen dağına gitmek üzere karargâhtan ayrılırlar. Büyük Anafarta mezarlığına gelene kadar hiçbir sorun yaşamazlar ancak rehberleri Türk onbaşı yolu şaşırınca İngiliz gemilerinin görüşüne girer ve ateşe tutulurlar. Sadece altı metre kadar yakınlarına bir bomba düşer. Ölümü yakından hissederler. ${ }^{98}$

24 Ağustos'ta Yalova'dan Kumköy’e ve Turşunköy’e giderler. Schreiner Kireçtepe'yi görmek ister. Bölge komutanı olan Alman subayı Willmers ${ }^{99}$ Ege denizindeki itilaf torpido botları ve destroyerleri bütün gün boyunca kıyıyı ateş altında tuttuklarından bunu gece yapmanın uygun olacağını söyler. ${ }^{100}$ Saat 11:00'de yola çıkarlar. Zaten sıcak ve boğucu olan havada fırın etkisi yapan uzun bir iletişim siperine girerler. Ağır ve zahmetli bir yürüyüşün nihayetinde büyük bir liman gibi aydınlatılmış olan Suvlakoyu görünür. Kireçtepe'ye ulaştıklarında Schreiner tepenin doğu yamacı üzerinde ve aşağısındaki küçük plato üzerindeki sert çatışmalarda ölenlerin düştükleri yerlere gömüldüğünü görür. ${ }^{101}$ Kendilerinin şimdi Osmanlı ve ANZAK askerlerinin ırk ve inançlarına bakılmaksızın birlikte yattıkları büyük ortak mezarlar arasında durduklarını düşünür. Üstelik sert kireçtaşından zeminin yapısı dolayısıyla

96 Bkz. İsmet Görgülü, On Yillık Harbin Kadrosu 1912-1922, Türk Tarih Kurumu Basımevi, Ankara, 1993, s. 91-92.

97 Bkz. Muzaffer Albayrak-Tuncay Yllmazer, a.g.e., s. 156.

98 Schreiner, a.g.e., s. 344.

99 Binbaşı Willmer 6 Ağustos'ta İngilizlerin beş tümenle çıkarma yaptıkları Suvla kıyılarını koruyan küçük bir Türk birliğinin başındaydı. Bu birlik Albay Mustafa Kemal’in komutasındaki Anafartalar Grubuna bağlıydı. Faaliyeti için bkz. Bkz. Edward J. Erickson, Size Ölmeyi Emrediyorum! Birinci Dünya Savaşı'nda Osmanlı Ordusu(Çev. M. Tanju Akad), Kitap Yay., İstanbul, 2011, s. 125.

10015 Ağustos'a kadar Willmers karargâhında çalışan Türk subayı Haydar Mehmet Bey’in günlüklerinden de "korunaklı yollardan" geçilebilen Kireçtepe'ye gitmenin tehlikeli bir yolculuk olduğu anlaşılmaktadır. Haydar Mehmet Alganer, a.g.e., s. 100.

101 Bayur İngiliz kuvvetlerinin 15/16 Ağustos'ta Suvla'nın kuzeyinde Kireçtepe'ye çetin ama sonuçsuz saldırılarda bulunduğu bilgisini verir. General Hamilton'un konu ile ilgili 17 Ağustos tarihli raporu buradaki çarpışmaların ne derece belirleyici olduklarını gösterir: “Teessüfle söylemeli ki, Türkler bizim bazı yeni birliklerimiz üzerinde manevi üstünlük sağlamışlardır...” Bkz. Yusuf Hikmet Bayur, a.g.e., s. 359. 
bunların gerektiği gibi gömülmesi mümkün olmamış, Türkler ellerinden geldiğince derin kazsalar da sığ yerdeki cesetleri tepeleme doldurmuşlardır. Schreiner ince bir toprak ve kaya tabakası yüzünden cesetlerin şimdiye kadar deneyimlediği en kötü kokuyu yaydığını yazar. Mevsim şartları da bu etkiyi çoğaltımış olmalıdır. İngilizlerin ileri pozisyonlarını görmek için Kireçtepe'nin üstüne çıkmak zorundadırlar, kokuyu bastırmak için ne yaptılarsa nafiledir. Schreiner hiçbir şeyin o kokunun üstesinden gelip onun korkunç yoğunluğu ile mücadele edemeyeceğini söyler. ${ }^{102}$

İtilaf askerlerinin dikkatlerini üzerlerine çekmemek için meşale kullanmamaktadırlar. İngiliz siperlerine yüz elli metre kadar yakındırlar. Kireçtepe’ye tırmanırken Türklerin siperlerini düzene sokmakla meşgul olduklarını görürler. Toprak hiçbir yerde 15 santimetreden daha derin olmadığından bu çok zor bir meşgaledir. Sı ğ hendekte siper oluşturmak için kum torbaları kullanılmaktadır. Schreiner buradan Kocaçimen dağı yamaçlarındaki tüfeklerin ve el bombalarının kullanıldığı, körfezdeki itilaf gemilerinden birinin de katıldığı bir çatışmaya şahit olur. Gece 02:00'deWillmers karargâhına dönerler. Schreiner, yolculuk, gürültü ve ağır kokunun yol açtığı şiddetli baş ağrısı ile kısa bir istirahatten sonra saat 06:00'da Willmers'in kendi bölgesini teftişine katılır. İletişim siperinde ilerlerken Ege denizi üzerinden gelen ateşe maruz kalırlar. Küçük bir koya inerler ancak bir İngiliz torpido botunun yaklaşması ile oradan ayrılmak zorunda kalırlar. Schreiner günlüğünde bu bahsi kapatırken, Türk de olsalar Anzak da olsalar, Suvla koyu arkasındaki o cehennem deliğinde savaşmak zorunda olan zavallılar için üzgün olduğunu yazar. ${ }^{103}$

Schreiner'in Çanakkale/Gelibolu'ya bu üçüncü seferi oldukça kısa sürer. Bunun nedeni İstanbul'daki Amerikan elçiliğinden aldığı bir telegramdır. İstanbul'a dönmenin en hızlı yolunun Çanakkale'de demirli olan bir torpido-bot aracılığıyla olacağını düşünür. Fakat onu iki sürpriz beklemektedir. Öncelikle mevzubahis geminin Osmanlı Donanma Komutanı Amiral Souchon'un bayrak gemisi olduğunu öğrenir. Ne var ki amiral belki de Amerikalı eşi dolayısıyla Amerikalılara karşı dostane hisler beslemektedir ve Amerikalı gazeteciyi gemisine davet eder. Saat 05:00'te Çanakkale'den ayrılırlar, Kilye koyundan hasta bir subayı gemiye alırlar. On dakika sonra Schreiner'in tecrübe ettiği en zorlu bombardıman olan Akbaş bombardımanı kadar ateşli bir girdaba girerler. Dolaylı ve yüksek atılan İngiliz bombalarının çoğu içinden geçmek zorunda oldukları boğaza düşer. Amiral gemisi Anadolu yakasına çok yakın seyreder. Saat 02:00'de torpido botun direksiyon dişlileri bozulur ve sonraki iki saat boyunca gelebilecek herhangi bir denizaltı için hazır av olarak suda hareketsiz dururlar. ${ }^{104} 29$ Ağustos günü sabahın ilk ışıklarıyla birlikte İstanbul'dadırlar.

102 Schreiner, a.g.e., s. 347.

103 Schreiner, a.g.e.,s. 348-349.

104 Schreiner'in gemide denizaltılara karşı bir savunma sistemi kurmaya çalışan Wellman isimli bir Alman subayla konuşması Osmanlı ordusunun teknoloji, mühimmat ve malzeme yokluğunu çarpıcı bir biçimde ortaya koyar. Wellman öfkelidir. Böyle bir sistem için ellerinde hem yeterli malzeme hem de doğru tür malzeme yoktur. Schreiner, a.g.e.,s. 350. 


\section{Sonuç}

George Abel Schreiner'in Çanakkale günlüğü ilgili literatüre önemli katkılar getirmektedir. Bir gazeteci kimliği ile yazılan bu günlük Çanakkale Savaşı'na şahitlik eden asker ya da sivillerin günlüklerinde genellikle rastlanmayan zengin ayrıntılarla doludur. Öncelikle bir mayın uzmanı ya da topçu subayının savaşın belli bir yönüne odaklanan anılarından çok daha geniş bir perspektifle kaleme alınmıştır. İkinci olarak yazar Çanakkale'de sınırlı bir süre bulunabilmiş ve savaş alanlarını ordu mensubu rehberlerin gözetiminde gezebilmiş gazetecilerden de daha fazlasını görmüş ve yazabilmiştir. Hem deniz savaşlarını hem de kara savaşlarını uzun süreli olarak ve özel izinle serbestçe dolaşarak izlemesi onu ayrıcalıklı kılmıştır. Ayrıca askeri geçmişi dolayısıyla savaş stratejileri ve teknolojileri konusunda bilgili olması onu benzerlerinin, hatta kendisiyle aynı şartlar altında birlikte çalışan Raymond Swing'in de önüne geçirmiştir. Sıra dışı gözlemciliği ve girişkenliği onu politikacıların, komutanların, diplomatların, sivil bürokratların, cephedeki din adamlarının ve elbette sıradan halkın tepkilerini de gözetip kaydetmeye sevk etmiştir. Sadece savaşın aktörleriyle değil iklim ve topografya gibi benzer günlüklerin genellikle ihmal ettiği faktörlerle de ilgilenmesi Schreiner'i ve yazdıklarını savaşın bütüncül bir tarihini yazma yolunda önemli bir kaynak haline getirmektedir. 


\section{KAYNAKÇA}

\section{Arşiv}

Başbakanlık Osmanlı Arşivi, Dâhiliye Nezareti Emniyet-i Umumiye Evrak Odası Kalemi Evrakı.

\section{Kitaplar}

Abdullah Fevzi Efendi, Çanakkale Cephesinde Bir Müderris(Yay. Haz. Ali Osman Koçkuzu), İz yay., İstanbul 2011.

Albayrak, Muzaffer -Yılmazer, Tuncay,Sorularla Çanakkale Muharebeleri I, Yeditepe Yay., İstanbul 2007.

Alganer, Haydar Mehmet Çanakkale Kara Savaşları Günlüğü, Deniz Basımevi, İstanbul 2010.

Bartlett, EllisAshmead, Çanakkale Gerçeğ i(Çev. Yüzbaşı Rahmi; Yay. Haz. Muzaffer Albayrak), Yeditepe Yay., İstanbul, İstanbul 2007.

Bayur, Yusuf Hikmet,Türk İnkılâbı Tarihi, Cilt III, Kısım II, Türk Tarih Kurumu, Ankara 1991.

Bursalı Mehmet Nihat, Büyük Savaşta Çanakkale Seferi, İlhami-Fevzi Matbaası, İstanbul 1926.

Çanakkale Savașının Bilinmeyen Cephesi: Hava Savaşları(Haz. Turan Tanyer), Türkiye Barolar Birliği, Ankara 2010.

Erickson,Edward J.,Size Ölmeyi Emrediyorum! Birinci Dünya Savaşı’nda Osmanlı Ordusu(Çev. M. Tanju Akad), Kitap Yay., İstanbu, 2011.

Görgülü, İsmet,On Ylllık Harbin Kadrosu 1912-1922, Türk Tarih Kurumu Basımevi, Ankara 1993.

Herbert,Aubrey -Morgenthau, Henry, Çanakkale / Devler Ülkesinde Devler Savaşı(Çev. Seyfi Say), Yeditepe Yay., İstanbul 2007.

Hersing, Otto,Çanakkale Denizaltı Savaşı(Çev. Bülent Erdemoğlu), Türkiye İş Bankası Kültür Yay., İstanbul 2009.

Koyuncu,A. -Keskin,Ö. -Sönmez,C. S.,Çanakkale Savaşları Bibliyografyası, Atatürk Araştırma Merkezi, Ankara 2010.

Mayın Grup Komutanı Binbaşı Nazmi Bey’in Günlüğüyle Çanakkale Deniz Savaşları(Yay. Haz. E. Şimşek - A. Güner), Deniz Basımevi, İstanbul 2010.

Morgenthau, Henry,AmbassadorMorgenthau'sStory, DoubleDay, Page\&Company, New York 1919.

Mühlman, Carl,Çanakkale Savaşı / Bir Alman Subayının Anıları(Çev. Sedat Umran), Timaș Yay., İstanbul 2009.

Oglander,C. F. Aspinall,Çanakkale Muharebeleri / Ingilizlerin Gelibolu Seferinin Resmi Tarihi (Terc: Muharrem Feyzi), Kanaat Kütüphanesi, İstanbul 1932. 
Schreiner, George Abel,From Berlin toBagdad, Harper\&Brothers, New York 1918.

Schreiner, George Abel,The CraftSinister, Harper\&Brothers, New York 1920.

Stern, Robert C.,Destroyer Battles / Epics of Naval Close Combat, Seaforth Publishing, Barnsley 2008.

Swing, Raymond, "GoodEvening!": A Professional Memoir, Harcourt, Brace\& World,New York, 1964.

Tevfik Rıza Bey, Çanakkale Günlükleri(Yay. Haz. T.Doğruöz-Y.Yücetürk-R.Gündoğdu), Kırklareli Üniversitesi Yay., Kırklareli 2012.

VonSanders, Liman,Türkiye'de Beş Sene, Yeditepe Yay., İstanbul 2006.

Winter,Jay -Prost, Antoine,The Great War in History / DebatesandControversies, 1914 tothePresent, Cambridge UniversityPress, New York 2005.

Yazman, Mehmet Şevki,Bir Subayın Kaleminden 'Türk Çanakkale' / Cephaneniz Yoksa Süngünüz Var, Yeditepe Yay., İstanbul 2008.

\section{Makaleler}

Albayrak, Muzaffer, “Çanakkale Savaşları Sırasında İstanbul'da Sosyal Hayat ve Alınan Askeri Tedbirler”, Gelibolu / Tarih, Efsane ve Anı(Ed: İ. G. Yumuşak-M. İlhan, İstanbul Medeniyet Üniversitesi, İstanbul 2013.

Duman, Selçuk, "Hüsameddin Bey’in Çevirilerine Göre Çanakkale Savaşları”, Türklük Bilimi Araştırmaları Dergisi, Sayı XXXIII, Bahar 2013.

Erdemir, Lokman,“Çanakkale Boğazı Müstahkem Mevkii İntepe Topçu Grubu'ndan Bir Subayın Günlüğü”, Çanakkale Araştırmaları Türk Yıllığı, Yıl 11, Sayı 14, Bahar 2013.

Esenkaya, Ahmet,“Çanakkale Cephesi’nde 19 Mart-24 Nisan 1915 Günleri”, Çanakkale Araştırmaları Türk Yıllı̆̆ı, Yıl 11, Sayı 14, Bahar 2013.

Semiz, Yaşar, "Çanakkale Denizaltı Savaşı (Nisan-Mayıs 1915) / Sultanhisar ve Muâvenet-i Milliye'nin Başarıları”, Selçuk Üniversitesi Türkiyat Araştırmaları Dergisi, Sayı 9, 2001.

Toumarkine, Alexandre,“Tanıklığın Önemi: Çanakkale Üzerine ‘Osmanlı’ Savaş Anıları”, Gallipoli in Retrospect 90 Years On / 90. Yıl Dönümünde Çanakkale Savaşlarını Düşünürken, Çanakkale 18 Mart Ünivrsitesi, Çanakkale, 2005.

Uzun, Ali,“Çanakkale Savaş Alanının Coğrafi Özellikleri ve Bazı Doğa Olaylarının Savaşın Kaderine Etkisi", Gelibolu / Tarih, Efsane ve Anı(Ed: İ. G. Yumuşak-M. İlhan, İstanbul Medeniyet Üniversitesi, İstanbul 2013. 


\section{Ekler}

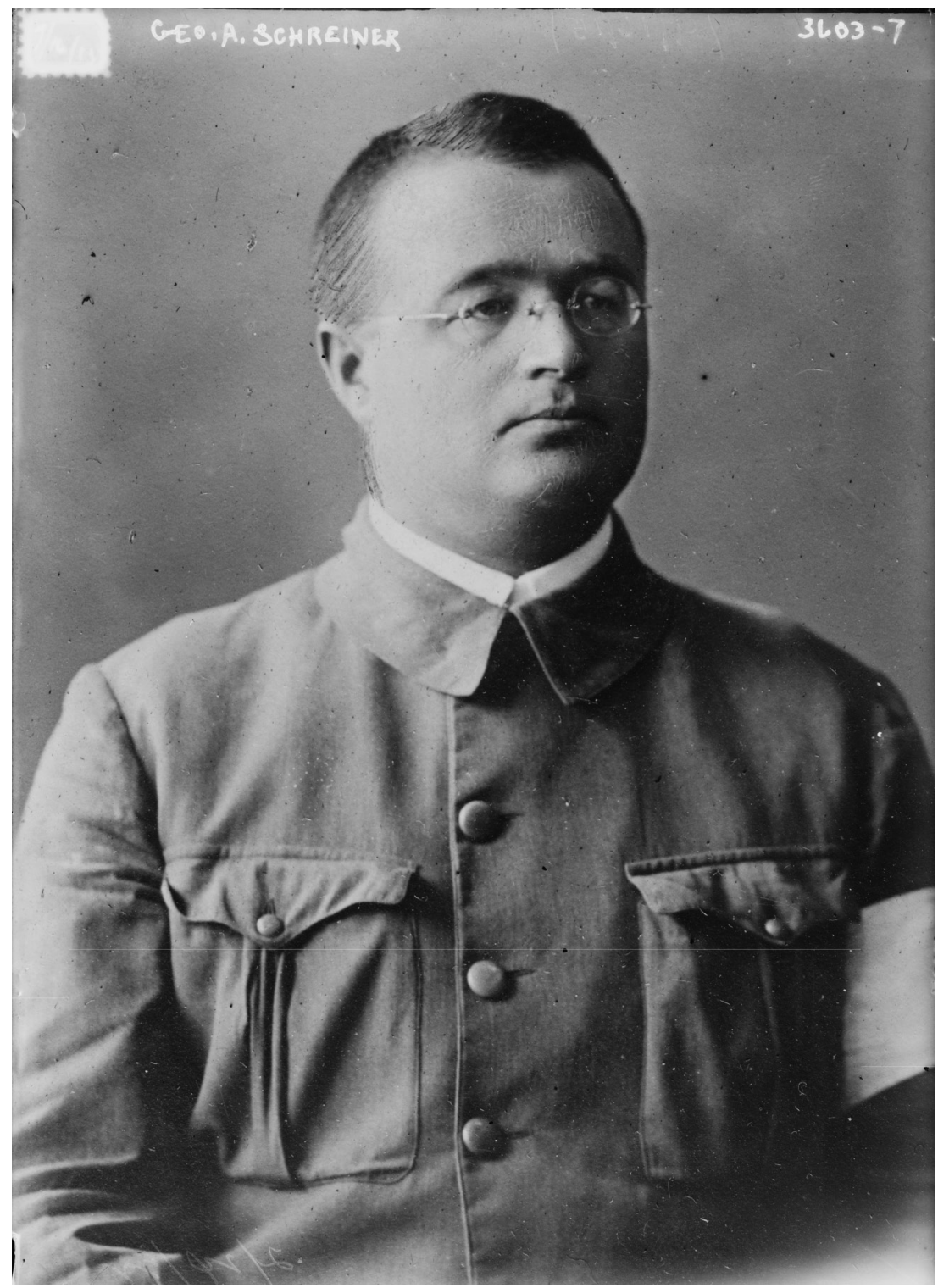

Resim 1- Abel Schreiner (Amerikan Kongre Kütüphanesi Arşivi) 
